\title{
A protocol for the intercomparison of marine fishery and ecosystem models: Fish-MIP v1.0
}

Derek P. Tittensor ${ }^{1,2}$, Tyler D. Eddy ${ }^{2,3}$, Heike K. Lotze ${ }^{2}$, Eric D. Galbraith ${ }^{4,5}$, William Cheung ${ }^{3}$, Manuel Barange ${ }^{6,7}$, Julia L. Blanchard ${ }^{8}$, Laurent Bopp ${ }^{9}$, Andrea Bryndum-Buchholz ${ }^{2}$, Matthias Büchner ${ }^{10}$, Catherine Bulman ${ }^{11}$, David A. Carozza ${ }^{12}$, Villy Christensen ${ }^{13}$, Marta Coll ${ }^{14,15,30}$, John P. Dunne ${ }^{16}$, Jose A. Fernandes ${ }^{7,17}$, Elizabeth A. Fulton ${ }^{11,18}$, Alistair J. Hobday ${ }^{11,18}$, Veronika Huber ${ }^{10}$, Simon Jennings ${ }^{19,20,21}$, Miranda Jones ${ }^{3}$, Patrick Lehodey ${ }^{22}$, Jason S. Link ${ }^{23}$, Steve Mackinson ${ }^{19}$, Olivier Maury ${ }^{24,25}$, Susa Niiranen ${ }^{26}$, Ricardo Oliveros-Ramos ${ }^{27}$, Tilla Roy ${ }^{9,28}$, Jacob Schewe ${ }^{10}$, Yunne-Jai Shin ${ }^{24,29}$, Tiago Silva ${ }^{19}$, Charles A. Stock ${ }^{16}$, Jeroen Steenbeek ${ }^{30}$, Philip J. Underwood ${ }^{1}$, Jan Volkholz ${ }^{10}$, James R. Watson ${ }^{31}$, and Nicola D. Walker ${ }^{19}$

${ }^{1}$ United Nations Environment Programme World Conservation Monitoring Centre, 219 Huntingdon Road,

Cambridge, CB3 0DL, UK

${ }_{2}^{2}$ Department of Biology, Life Sciences Centre, Dalhousie University, 1355 Oxford Street, Halifax, N.S., B3H 4R2, Canada

${ }^{3}$ Nippon Foundation-Nereus Program, Institute for the Oceans and Fisheries, The University of British Columbia, Vancouver,

B.C., V6T 1Z4, Canada

${ }^{4}$ Institució Catalana de Recerca i Estudis Avançats (ICREA), 08010 Barcelona, Spain

${ }^{5}$ Institut de Ciència i Tecnologia Ambientals (ICTA) and Department of Mathematics, Universitat Autonoma de Barcelona, 08193 Barcelona, Spain

${ }^{6}$ Fisheries and Aquaculture Policy and Resources Division, Food and Agriculture Organisation of the United Nations (FAO), 00153 Rome, Italy

${ }^{7}$ Plymouth Marine Laboratory, Prospect Place, The Hoe, Plymouth, PL13 DH, UK

${ }^{8}$ Institute for Marine and Antarctic Studies, University of Tasmania, 20 Castray Esplanade, Battery Point. TAS. 7004,

Private Bag 129, Hobart, TAS 7001, Australia

${ }^{9}$ Institut Pierre-Simon Laplace/Laboratoire des Sciences du Climat et de l'Environnement, CNRS/CEA/UVSQ,

CE Saclay, Orme des Merisiers, 91191 Gif sur Yvette, France

${ }^{10}$ Potsdam Institute for Climate Impact Research, Telegrafenberg A56, 14473 Potsdam, Germany

${ }^{11}$ CSIRO Oceans and Atmosphere, GPO Box 1538, Hobart, Tasmania 7001, Australia

${ }^{12}$ Department of Earth and Planetary Sciences, McGill University, 3450 University Street, Montreal, H3A 0E8, Canada

${ }^{13}$ Institute for the Oceans and Fisheries, University of British Columbia, 2202 Main Mall, Vancouver BC, V6T 1Z4, Canada

${ }^{14}$ Institute of Marine Science (ICM-CSIC), Passeig Marítim de la Barceloneta, no 37-49, 08003 Barcelona, Spain

${ }^{15}$ Institut de Recherche pour le Développment, UMR MARBEC \& LMI ICEMASA, University of Cape Town,

Private Bag X3, Rondebosch, Cape Town 7701, South Africa

${ }^{16}$ Geophysical Fluid Dynamics Laboratory, National Oceanic and Atmospheric Administration, Princeton, NJ 08540, USA

${ }^{17}$ AZTI, Herrera Kaia, Portualdea z/g, 20110 Pasaia (Gipuzkoa), Spain

${ }^{18}$ Centre for Marine Socioecology, University of Tasmania, 20 Castray Esplanade, Battery Point, Tasmania, 7004, Australia

${ }^{19}$ Centre for Environment, Fisheries and Aquaculture Science (Cefas), Lowestoft Laboratory, Lowestoft, NR33 0HT, UK

${ }^{20}$ School of Environmental Sciences, University of East Anglia, Norwich Research Park, Norwich, NR4 7TJ, UK

${ }^{21}$ International Council for the Exploration of the Sea, H. C. Andersens Blvd 44-46, 1553 København V, Denmark

${ }^{22}$ CLS, 11 rue Hermes 31520, Ramonville Saint Agne, France

${ }^{23}$ National Oceanic and Atmospheric Administration, National Marine Fisheries Service, 166 Water Street, Woods Hole, MA 02543, USA

${ }^{24}$ IRD (Institut de Recherche pour le Développement) - UMR 248 MARBEC (IRD-IFREMER-CNRS-Université Montpellier), av Jean Monnet CS 30171,

34203 Sète cedex, France 
${ }^{25}$ University of Cape Town, Dept. of Oceanography - International Lab. ICEMASA Private Bag X3, Rondebosch 7701, Cape Town, South Africa

${ }^{26}$ Stockholm Resilience Centre, Stockholm University, Kräftriket 2B, 11419 Stockholm, Sweden

${ }^{27}$ Instituto del Mar del Perú (IMARPE). Gamarra y General Valle s/n Chucuito, Callao, Perú

${ }^{28}$ ECOCEANA (Ecosystem, Climate and Ocean Analysis), 57 Rue Archereau, 75019 Paris, France

${ }^{29}$ University of Cape Town, Marine Research (MA-RE) Institute, Department of Biological Sciences, Private Bag X3, Rondebosch 7701, South Africa

${ }^{30}$ Ecopath International Initiative (EII), 08193 Barcelona, Spain

${ }^{31}$ College of Earth, Ocean and Atmospheric Sciences, Oregon State University, Corvallis, OR 97330, USA

Correspondence: Derek P. Tittensor (derek.tittensor@unep-wcmc.org)

Received: 23 August 2017 - Discussion started: 6 October 2017

Revised: 23 December 2017 - Accepted: 13 February 2018 - Published: 13 April 2018

Abstract. Model intercomparison studies in the climate and Earth sciences communities have been crucial to building credibility and coherence for future projections. They have quantified variability among models, spurred model development, contrasted within- and among-model uncertainty, assessed model fits to historical data, and provided ensemble projections of future change under specified scenarios. Given the speed and magnitude of anthropogenic change in the marine environment and the consequent effects on food security, biodiversity, marine industries, and society, the time is ripe for similar comparisons among models of fisheries and marine ecosystems. Here, we describe the Fisheries and Marine Ecosystem Model Intercomparison Project protocol version 1.0 (Fish-MIP v1.0), part of the Inter-Sectoral Impact Model Intercomparison Project (ISIMIP), which is a cross-sectoral network of climate impact modellers. Given the complexity of the marine ecosystem, this class of models has substantial heterogeneity of purpose, scope, theoretical underpinning, processes considered, parameterizations, resolution (grain size), and spatial extent. This heterogeneity reflects the lack of a unified understanding of the marine ecosystem and implies that the assemblage of all models is more likely to include a greater number of relevant processes than any single model. The current Fish-MIP protocol is designed to allow these heterogeneous models to be forced with common Earth System Model (ESM) Coupled Model Intercomparison Project Phase 5 (CMIP5) outputs under prescribed scenarios for historic (from the 1950s) and future (to 2100) time periods; it will be adapted to CMIP phase 6 (CMIP6) in future iterations. It also describes a standardized set of outputs for each participating Fish-MIP model to produce. This enables the broad characterization of differences between and uncertainties within models and projections when assessing climate and fisheries impacts on marine ecosystems and the services they provide. The systematic generation, collation, and comparison of results from Fish-MIP will inform an understanding of the range of plausible changes in marine ecosystems and improve our capacity to define and convey the strengths and weaknesses of model-based advice on future states of marine ecosystems and fisheries. Ultimately, Fish-MIP represents a step towards bringing together the marine ecosystem modelling community to produce consistent ensemble medium- and long-term projections of marine ecosystems.

\section{Introduction}

The ocean provides nearly half of global primary production (Field et al., 1998), hosts $25 \%$ of eukaryotic species (Mora et al., 2011), provides $11 \%$ of global animal protein consumed by humans (FAO, 2014), and is a source of livelihoods for millions (Sumaila et al., 2012). Yet the pace and magnitude of projected climate change over the coming century, in combination with fisheries exploitation and a raft of other human impacts, suggests that marine ecosystems will remain under considerable pressure in the midterm to long term (Pörtner et al., 2014; UN, 2016). Identification of the potential future effects of these pressures, even with high uncertainty (Payne et al., 2016), is required to anticipate the impacts of environmental change on ecosystem resilience (Bernhardt and Leslie, 2013), biodiversity conservation (Cheung et al., 2016a; Queirós et al., 2016), socio-economics (Fernandes et al., 2017), and food security (Barange et al., 2014; Merino et al., 2012). Marine ecosystem models give us an approach to meeting this goal by providing scenario-driven projections of future fisheries production (e.g. Blanchard et al., 2012; Fernandes et al., 2016, 2017; Lehodey et al., 2015; Mullon et al., 2016), marine ecosystem structure and functioning (Jennings and Collingridge, 2015), and species compositions and distributions (Jones and Cheung, 2015) under global change.

The scientific understanding of the physical climate system and its response to anthropogenic perturbation has profited enormously from model intercomparison efforts like the Coupled Model Intercomparison Project (CMIP; Taylor et al., 2012) and the Ocean Model Intercomparison Project 
(OMIP; Griffies et al., 2016). CMIP and other efforts have highlighted differences among models, provided ranges of potential climate change responses and ensemble projections for end users, and allowed the outputs of individual analyses to be interpreted in a broader context. They have also provided a quantification of the relative contributions of different sources of uncertainty to projected uncertainties in climate responses (Hawkins and Sutton, 2009; Payne et al., 2016).

In addition to model intercomparison experiments for the climate and ocean system, a systematic intercomparison and assessment of impact models - including the marine realm is similarly essential for understanding the impacts of (and associated uncertainty around) climate change on important biological and human systems (Barange et al., 2014). Such impact models typically use the outputs of scenariodriven Earth system models (ESMs), individually or as ensembles, as inputs to project the effects of these on sectors such as agriculture or energy. The Inter-Sectoral Impact Model Intercomparison Project (ISIMIP; www.isimip.org) was set up to enhance consistency among climate impact studies across different sectors, including food production, ecosystems and biodiversity, freshwater availability, and human health among others (Huber et al., 2014; Schellnhuber et al., 2013). It does so chiefly through providing common climate and socio-economic input data and defining a common set of simulation experiments (Warszawski et al., 2013).

Although there have been prior intercomparisons of fisheries and marine ecosystem models, they have been limited to a few models applied to local or regional case studies (Coll et al., 2008; Fulton and Smith, 2004; Jones et al., 2013; Shin et al., 2004; Smith et al., 2011; Travers et al., 2010) or to lower trophic levels of the global ocean rather than the whole ecosystem (see the Marine Ecosystem Model Intercomparison Project MAREMIP at pft.ees.hokudai.ac. jp/maremip/index.shtml; Bopp et al., 2013). Here, we describe the Fisheries and Marine Ecosystem Model Intercomparison Project (Fish-MIP) protocol v1.0, which intends to standardize to the extent possible input variables to fisheries and marine ecosystem models and to analyse, compare, and disseminate outputs from multiple models to assess climate and fisheries impacts on marine ecosystems and the services they provide, such as potential future fisheries catches. The Fish-MIP protocol has been designed in coordination with the other ISIMIP sectors and forcings, which will enhance consistency when looking at synergistic impacts and considering multisectoral aspects such as global food security and economic impacts. This article describes the Fish-MIP protocol and provides background on the range of existing ecosystem models, including the resolved processes, theoretical approaches, and specifications, and provides the foundation for forthcoming studies under the umbrella of this project. We emphasize here that Fish-MIP is continuously ongoing in terms of development and refinement: see www.isimip.org/gettingstarted/ marine-ecosystems-fisheries/forupdates. While many FishMIP model runs for the $v 1.0$ protocol (ISIMIP simulation round $2 \mathrm{~A}$ ) have been completed, some are still in progress or under analysis, and results will be published once runs are complete (see Blanchard et al., 2017, though).

The scope of Fish-MIP v1.0 is global and regional using fisheries and marine ecosystem models able to make historical ( $\sim$ the 1950s onwards) and medium- to long-term (defined here as $\sim 2030-2100$ ) projections of ecosystem structure, dynamics, and function using the same set of scenarios and reanalyses of climate change and variability. Singlespecies and multispecies tactical models for fisheries stock assessment and management are therefore excluded; a complementary initiative presently underway under the auspices of the intergovernmental organizations ICES (www.ices.dk) and PICES (www.pices.int), the Strategic Initiative on Climate Change effects of Marine Ecosystems (SICCME), aims to fill this gap. The long time horizon of Fish-MIP means that outputs are most likely to inform those focusing on long-term changes in the global and regional environment and future policy development, such as the Intergovernmental Panel on Climate Change (IPCC), the Intergovernmental Platform on Biodiversity and Ecosystem Services (IPBES), and the United Nations Regular Process of work on the Sustainable Development Goals (SDGs). Results may also be of interest to national bodies and management authorities interested in scenarios or species distribution shifts (ICES, 2016). Questions of interest include the effect of climate impacts on the distribution, diversity, and productivity of fishes and fisheries, exploration of global fisheries scenarios and projections and their implications for food security (Béné et al., 2015), and the conservation status of marine fauna and their role in biogeochemical cycles.

The development of marine ecosystem models, which aim to simulate the structure, dynamics, production, and functional role of marine biota interacting with each other and their environment across multiple trophic levels, was initiated at least 4 decades ago (Andersen and Ursin, 1977; Polovina, 1984; Sheldon et al., 1977) and somewhat earlier for efforts with less-resolved biology (Hamblin, 2005). More recently, to support ecosystem-based fisheries management, marine ecosystem models have been applied to assess changes in ecosystem structure and function under fisheries and environmental drivers (Fulton, 2010). Unlike in the physical and chemical sciences, where there is often clarity about fundamental representations and processes driven by underlying theory or experimentation, the development of marine ecosystem models has been approached from many perspectives, reflecting differences in scientific and management objectives, theoretical frameworks, modelling structures and parameterizations, input data needs, resolutions (spatial, temporal, vertical, process, and taxonomic), and process complexity. They include differing assumptions of top-down, bottom-up, or mixed trophic control, the role of species as opposed to trophic groups, functional groups, or 
body size classes, and the characterization of growth, mortality, recruitment, and movement.

Applying such a range of different model types will provide useful insights into the effects of climate variability and change on marine ecosystems and fisheries, but also makes intercomparisons challenging. Unsurprisingly, the inputs to and outputs from such models are diverse and difficult to standardize, with no common set of defined output metrics that can be used for comparison purposes. Here we review the models participating in the first round of Fish-MIP simulations (using CMIP5 ESM output), describe our intercomparison protocol, highlight the challenges that have arisen in developing this protocol, and detail the approaches that we have used to resolve these difficulties. We also identify future pathways for Fish-MIP, including the use of CMIP6 output and refined fisheries scenarios. The lessons learned here also apply to other marine model comparisons and will help to guide the development of new models to investigate patterns of change in the future oceans.

\section{Marine ecosystem models participating in Fish-MIP}

The last 3 decades have seen a profusion of marine ecosystem models being developed, with many emerging during the last decade (Fulton and Link, 2014; Nielsen et al., 2017; Peck et al., 2016). Fish-MIP is open to all developers and users of marine ecosystem models who are willing to run consistent scenarios to facilitate comparisons. All models in the intercomparison must be documented in appropriate venues, such as the peer-reviewed literature, to ensure that descriptions of the model are widely available and that key features and parameterizations are codified and model runs repeatable. Here we introduce the model types that have been included in Fish-MIP to date, recognizing that these are a subset of the many available and extensively reviewed elsewhere (Fulton and Link, 2014; Hollowed et al., 2000; Plagányi, 2007; Plagányi et al., 2011, 2014; Townsend et al., 2008; Travers et al., 2007).

\subsection{Model heterogeneity}

The diversity of model types participating in Fish-MIP and some of their unique characteristics are summarized in Table 1. One constant feature across all the participating models is the inclusion of multiple species or functional groups (typically an aggregation of species or food web elements) and environmental drivers. These minimum specifications are in line with the need to characterize the transfer of biomass from primary producers to mid- and upper trophic level organisms, which are often those impacted or used by society or of conservation interest. Among the key differences therein, the spatial resolution of participating models ranges from simple 0-D boxes encompassing model parameters averaged over a large area, to irregularly shaped polygons cor- responding to depth and bathymetric features, to regional models gridded at $0.1 \times 0.1^{\circ}$, to global models gridded at resolutions typically around $0.5 \times 0.5^{\circ}$ to $1 \times 1^{\circ}$. Some models are fully or partially vertically resolved, while others consider depth implicitly through food web interactions and habitat preference patterns or do not model the vertical dimension at all. The movement of fish can be ignored, defined by discrete rules between adjacent grid cells, driven by climate niche models, or expressed through formal advectiondiffusion systems of equations. Fisheries are elaborated to differing degrees, from complete absence, to a simple fishing mortality term, to more elaborate fishing effort allocation formulations.

The wide array of modelling approaches leads to a wide array of input data requirements (Table 2). Some models use a single forcing variable, often a primary production anomaly or estimate derived from the output of a regional oceanbiogeochemistry or a global Earth system model (ESM), while others use multiple variables directly. While all the global Fish-MIP models use temperature as an input variable, some use fully vertically resolved 3-D data, others use temperature averaged over a near-surface layer such as the mixed layer, a few wide layers (e.g. epipelagic, upper mesopelagic, and lower mesopelagic layers), sea-surface and sea-bottom temperature, or sea-surface temperature only (Table 2). Some models require or can use additional inputs other than primary production and temperature, such as total alkalinity, nutrients, light (photosynthetically active radiation), or a turbulent mixing parameter. In terms of temporal scales, most models run on monthly or yearly time steps, though others run on very fine timescales of a day or less, creating another axis of variation when considering model differences and input requirements.

In terms of model outputs, all current Fish-MIP models can produce a measure of biomass density for all consumers and for particular size classes (which itself may require translation from functional groups to sizes classes or classification of species under a particular class if body length is not tracked; Table 3). Most models also consider some measure of fisheries production (e.g. catches, fisheries landings, mortality rates). It is worth highlighting the difference between models that predict catch from effort and fish biomass versus those that are forced using catch data: in the former, catch is an output, while in the latter, it is an input, and measures of fisheries production cannot thus be calculated. Further, some models enable statistical fitting to catch or effort data in which case other parameters are estimated (such as fishing mortality rates).

The great heterogeneity in input data requirements presented a large challenge when developing the Fish-MIP protocol and constrained the set of ESM outputs (from CMIP v5) that could be used. Forcing using identical ESM outputs is not feasible as the requirements and options for each FishMIP model differ (Table 2). Instead, participating models are forced using standardized inputs for those variables that are 
Table 1. A taxonomy of marine ecosystem models taking part in the Fish-MIP project. See also Tables 2 and 3 for the degree of heterogeneity in inputs and outputs that also exists across the model types.

\begin{tabular}{|c|c|c|c|c|c|c|}
\hline Fish-MIP model & Brief model description & Domain & Defining features and key processes & $\begin{array}{l}\text { Spatial and temporal scale } \\
\text { and vertical resolution }\end{array}$ & Taxonomic scope & Key reference \\
\hline \multicolumn{7}{|c|}{ Species distribution models - statistical relationships between species and environment; focus on role of habitat change and population dynamics } \\
\hline DBEM & $\begin{array}{l}\text { The DBEM defines a bioclimatic } \\
\text { envelope for each species and simu- } \\
\text { lates changes in abundance and car- } \\
\text { rying capacity under a varying envi- } \\
\text { ronment. }\end{array}$ & Global & $\begin{array}{l}\text { Carrying capacity is a function of } \\
\text { the environment and species' pref- } \\
\text { erences for these factors. Movement } \\
\text { of adults is driven by a gradient of } \\
\text { habitat suitability and density. Lar- } \\
\text { val dispersal is dependent on cur- } \\
\text { rents and temperature. Growth, re- } \\
\text { production, and mortality are depen- } \\
\text { dent on oxygen, pH, and tempera- } \\
\text { ture. }\end{array}$ & $\begin{array}{l}1 / 2 \times 1 / 2^{\circ} \text {; model } \\
\text { outputs are annual average. } \\
\text { Vertical dimension implicit } \\
\text { through species niche } \\
\text { preferences. }\end{array}$ & $\begin{array}{l}\text { Fish and invertebrate } \\
\text { species (primarily } \\
\text { commercial). }\end{array}$ & $\begin{array}{l}\text { Cheung et } \\
\text { al. (2011) }\end{array}$ \\
\hline SS-DBEM & $\begin{array}{l}\text { SS-DBEM is based on the DBEM } \\
\text { and the macroecological model, } \\
\text { projects changes in species distribu- } \\
\text { tion, abundance, and body size, and } \\
\text { includes population dynamics, dis- } \\
\text { persal, and competition. }\end{array}$ & Global & $\begin{array}{l}\text { Key processes include ecophysiol- } \\
\text { ogy, population dynamics, dispersal, } \\
\text { trophic interactions, fishing mortal- } \\
\text { ity, and habitat suitability. }\end{array}$ & $\begin{array}{l}1 / 2 \times 1 / 2^{\circ} \text { and } \\
\text { yearly. Often aggregated } \\
\text { into management or ecolog- } \\
\text { ical meaningful units (e.g. } \\
\text { EEZ, LMEs, or ICES ar- } \\
\text { eas). Vertical dimension im- } \\
\text { plicit through species niche } \\
\text { preferences. }\end{array}$ & $\begin{array}{l}\text { All trophic levels of fish and } \\
\text { invertebrates. }\end{array}$ & $\begin{array}{l}\text { Fernandes et } \\
\text { al. (2013) }\end{array}$ \\
\hline \multicolumn{7}{|c|}{ Trophodynamic models - structured based on species interactions and transfer of energy across trophic levels } \\
\hline $\begin{array}{l}\text { Ecopath with } \\
\text { Ecosim (EwE) }\end{array}$ & $\begin{array}{l}\text { Ecopath with Ecosim is a mass- } \\
\text { balance food web model that ac- } \\
\text { counts for the flow of biomass be- } \\
\text { tween trophic groups. }\end{array}$ & Regional & $\begin{array}{l}\text { Includes a mass-balance compo- } \\
\text { nent (Ecopath), a temporal dy- } \\
\text { namic component (Ecosim), and a } \\
\text { spatial-temporal dynamic compo- } \\
\text { nent (Ecospace). Typically resolved } \\
\text { to a mix of functional groups and } \\
\text { key species. }\end{array}$ & $\begin{array}{l}\text { Spatial resolution varies } \\
\text { from local to global, grid- } \\
\text { ded configuration. Flexible, } \\
\text { typically running in } \\
\text { monthly time steps. Depth } \\
\text { dimension is considered } \\
\text { implicitly through food } \\
\text { web interactions and } \\
\text { habitat preference } \\
\text { pattern. }\end{array}$ & $\begin{array}{l}\text { All trophic levels and tax- } \\
\text { onomic groups can be in- } \\
\text { cluded as biomass pools or } \\
\text { age-structured life history } \\
\text { stanzas. }\end{array}$ & $\begin{array}{l}\text { Christensen and } \\
\text { Walters (2004) }\end{array}$ \\
\hline EcoOcean & $\begin{array}{l}\text { EcoOcean is a global food web } \\
\text { model based on the EwE framework } \\
\text { designed to evaluate the impact of } \\
\text { climate change and human pressure } \\
\text { on marine ecosystems. }\end{array}$ & Global & $\begin{array}{l}\text { Atmosphere-ocean circulation } \\
\text { model (COBALT); EwE food web } \\
\text { model with Ecosim and Ecospace } \\
\text { habitat capacity model; fisheries ef- } \\
\text { fort global gravity model. }\end{array}$ & $\begin{array}{l}\text { Global model. Spatial reso- } \\
\text { lution is } 1 / 2 \times 1 / 2^{\circ} \text { and out- } \\
\text { puts are annual or monthly } \\
\text { averages. Depth dimension } \\
\text { is considered } \\
\text { implicitly through food } \\
\text { web interactions and } \\
\text { habitat preference pattern. }\end{array}$ & $\begin{array}{l}\text { All trophic levels and tax- } \\
\text { onomic groups included as } \\
\text { biomass pools ( } 51 \text { groups). }\end{array}$ & $\begin{array}{l}\text { Christensen et } \\
\text { al. (2015) }\end{array}$ \\
\hline \multicolumn{7}{|c|}{ Size-based models - developed from food web, macroecological, and life history theory for exploration of community size spectra } \\
\hline $\begin{array}{l}\text { Macroecological } \\
\text { model }\end{array}$ & $\begin{array}{l}\text { A static model, which uses minimal } \\
\text { inputs together with ecological and } \\
\text { metabolic scaling theory to predict } \\
\text { mean size composition and abun- } \\
\text { dance of animals (including fish). }\end{array}$ & Global & $\begin{array}{l}\text { Provides a simple size-based char- } \\
\text { acterization of marine ecosystems. } \\
\text { Relies on estimates of predator- } \\
\text { prey mass ratios, transfer efficiency, } \\
\text { and changing metabolic demands } \\
\text { with body mass and temperature } \\
\text { to predict body mass distributions } \\
\text { and abundance of marine consumers } \\
\text { from phytoplankton primary pro- } \\
\text { duction and environmental temper- } \\
\text { ature. Ignores non-phytoplankton } \\
\text { production and animal movement. }\end{array}$ & $\begin{array}{l}\text { Static equilibrium model, } \\
\text { typically applied at scales } \\
\text { from } 0.5 \times 0.5^{\circ} \text { grids to } \\
\text { large marine ecosystems; } \\
\text { forced with annual or } \\
\text { monthly mean environmen- } \\
\text { tal variables. Single vertical } \\
\text { (surface-integrated) layer. }\end{array}$ & $\begin{array}{l}\text { Species are not resolved, } \\
\text { only body mass classes. }\end{array}$ & $\begin{array}{l}\text { Jennings and } \\
\text { Collingridge (2015) }\end{array}$ \\
\hline $\begin{array}{l}\text { Dynamic } \\
\text { Pelagic-Benthic } \\
\text { Model (DPBM) }\end{array}$ & $\begin{array}{l}\text { A functional trait-based size spec- } \\
\text { trum model that joins a pelagic } \\
\text { predator size spectra model with } \\
\text { a benthic detritivore size spectrum; } \\
\text { can include herbivores or other } \\
\text { groups that do not feed according to } \\
\text { size and unstructured resources. }\end{array}$ & $\begin{array}{l}\text { Global or } \\
\text { regional }\end{array}$ & $\begin{array}{l}\text { Individual processes of predation, } \\
\text { food-dependent growth, mortality, } \\
\text { and reproduction give rise to emer- } \\
\text { gent size spectra for each functional } \\
\text { group. Can be linked to GCMs, re- } \\
\text { gional models, or observations via } \\
\text { parameterizing phytoplankton and } \\
\text { zooplankton size spectra, detritus, } \\
\text { and/or temperature. }\end{array}$ & $\begin{array}{l}\text { Spatial scale of grid is flex- } \\
\text { ible and dependent on in- } \\
\text { puts; temporal scale daily or } \\
\text { weekly; two vertical layers } \\
\text { (sea surface and sea floor). }\end{array}$ & $\begin{array}{l}\text { Broadly represents } \\
\text { "pelagic" fish predators } \\
\text { and } \\
\text { "benthic" invertebrates but } \\
\text { can include herbivorous } \\
\text { fish; flexible functional } \\
\text { groups. }\end{array}$ & $\begin{array}{l}\text { Blanchard et } \\
\text { al. (2012) }\end{array}$ \\
\hline BOATS & $\begin{array}{l}\text { Combines size-based ecological } \\
\text { theory and metabolic constraints } \\
\text { to calculate the production of } \\
\text { fish, is resolved across multiple size } \\
\text { spectra, and applies a coupled } \\
\text { economic model to determine effort } \\
\text { and harvest based on economic } \\
\text { boundary conditions. }\end{array}$ & $\begin{array}{l}\text { Global or } \\
\text { regional }\end{array}$ & $\begin{array}{l}\text { Applies empirical parameterizations } \\
\text { to describe phytoplankton commu- } \\
\text { nity structure, trophic transfer of pri- } \\
\text { mary production from phytoplank- } \\
\text { ton to fish, growth rates, and natu- } \\
\text { ral mortality. Model parameters are } \\
\text { calibrated against observed using a } \\
\text { Monte Carlo technique. Explicitly } \\
\text { models the evolution of effort and } \\
\text { harvest. Recruitment is dependent } \\
\text { on stock size and the environment, } \\
\text { and simple life history features are } \\
\text { resolved. }\end{array}$ & $\begin{array}{l}\text { Flexible spatial scale; } \\
\text { typically global at } 1 \times 1^{\circ} ; \\
\text { monthly timestep; single } \\
\text { vertical (surface-integrated) } \\
\text { layer. }\end{array}$ & $\begin{array}{l}\text { All commercial species rep- } \\
\text { resented by three groups, } \\
\text { defined in terms of the } \\
\text { asymptotic mass. }\end{array}$ & $\begin{array}{l}\text { Carozza et } \\
\text { al. (2016) }\end{array}$ \\
\hline
\end{tabular}


Table 1. Continued.

\begin{tabular}{|c|c|c|c|c|c|c|}
\hline Fish-MIP model & Brief model description & Domain & Defining features and key processes & $\begin{array}{l}\text { Spatial and temporal scale } \\
\text { and vertical resolution }\end{array}$ & Taxonomic scope & Key reference \\
\hline POEM & $\begin{array}{l}\text { A mechanistic ecosystem model that } \\
\text { uses body size as the basis of inter- } \\
\text { action. Offline coupled to an Earth } \\
\text { system model using zooplankton } \\
\text { biomass and mortality fields to force } \\
\text { ecosystem dynamics. }\end{array}$ & Global & $\begin{array}{l}\text { Simple size-based relationships de- } \\
\text { fined by empirical allometric rela- } \\
\text { tionships are used to model ecologi- } \\
\text { cal interactions. }\end{array}$ & $\begin{array}{l}\text { Spatial scale } 1 \times 1^{\circ} \text {; daily } \\
\text { timestep; single vertical } \\
\text { layer representing upper } \\
200 \mathrm{~m} \text {. }\end{array}$ & $\begin{array}{l}\text { One or two "ecotypes", e.g. } \\
\text { a piscivore or a planktivore. }\end{array}$ & $\begin{array}{l}\text { Watson et } \\
\text { al. (2015) }\end{array}$ \\
\hline \multicolumn{7}{|c|}{ Composite (hybrid) models - including multiple (e.g. size, age, trophic, physical, and other) model formulations in system representation } \\
\hline Atlantis & $\begin{array}{l}\text { Atlantis is a whole ecosystem } \\
\text { model taking a transport model de- } \\
\text { rived from hydrodynamic or GCM } \\
\text { output that sets the conditions for a } \\
\text { full representation of the food web } \\
\text { and human users. }\end{array}$ & Regional & $\begin{array}{l}\text { Modular (multiple options per pro- } \\
\text { cess). Includes age structure and } \\
\text { major ecological processes such } \\
\text { as full life history closure, gape- } \\
\text { limited predation, habitats, move- } \\
\text { ment, biogeochemical nutrient cy- } \\
\text { cling, and a range of effort alloca- } \\
\text { tion options. }\end{array}$ & $\begin{array}{l}\text { 3-D spatial polygons } \\
\text { matched to biophysical } \\
\text { features; vertically resolved } \\
\text { using "slab" layers (with } \\
\text { finer layers and the surface } \\
\text { and thicker at depth). } \\
\text { Timestep is flexible, typi- } \\
\text { cally 6-24h. }\end{array}$ & $\begin{array}{l}\text { All trophic levels and } \\
\text { taxonomic groups can be } \\
\text { represented using a mix } \\
\text { of biomass pools and age- } \\
\text { structured populations. } \\
\text { Typically resolved to a mix } \\
\text { of functional groups and } \\
\text { key species. }\end{array}$ & $\begin{array}{l}\text { Fulton et } \\
\text { al. (2011) }\end{array}$ \\
\hline OSMOSE & $\begin{array}{l}\text { The higher-trophic-level model OS- } \\
\text { MOSE (Object-oriented Simulator } \\
\text { of Marine ecOSystems Exploita- } \\
\text { tion) is a spatial multispecies and } \\
\text { individual-based model which fo- } \\
\text { cuses on fish species. Its current } \\
\text { structure embeds a coupling with } \\
\text { hydrodynamic and biogeochemical } \\
\text { models. }\end{array}$ & Regional & $\begin{array}{l}\text { Trophic interactions are size-based } \\
\text { so the modelled food webs are dy- } \\
\text { namic. The whole life cycle of } \\
\text { the modelled species is represented } \\
\text { (migration, food-dependent growth, } \\
\text { reproduction, and mortality), with } \\
\text { tracking of all life stages (from } \\
\text { eggs to terminal age) in space and } \\
\text { time. Provides size-, age-, species-, } \\
\text { and trophic-level-based indicators in } \\
\text { output. }\end{array}$ & $\begin{array}{l}\text { Flexible. Typically, res- } \\
\text { olution of } 1 / 6^{\circ} \text { and a } \\
\text { weekly time step. Spatially } \\
\text { resolved in 2-D; the vertical } \\
\text { distribution of species is } \\
\text { handled through a matrix of } \\
\text { accessibility. }\end{array}$ & $\begin{array}{l}\text { Fish and invertebrate } \\
\text { species and functional } \\
\text { groups. }\end{array}$ & $\begin{array}{l}\text { Travers et } \\
\text { al. }(2009)\end{array}$ \\
\hline SEAPODYM & $\begin{array}{l}\text { SEAPODYM is an Eulerian mod- } \\
\text { elling framework including func- } \\
\text { tional groups of lower and mid- } \\
\text { trophic levels and population dy- } \\
\text { namics of target species; developed } \\
\text { for investigating spatial pelagic fish } \\
\text { population dynamics under the in- } \\
\text { fluence of fishing and environment. }\end{array}$ & $\begin{array}{l}\text { Regional or } \\
\text { global }\end{array}$ & $\begin{array}{l}\text { Functional groups of zooplankton } \\
\text { and micronekton are simulated and } \\
\text { used with physical and biogeochem- } \\
\text { ical variables to define the habi- } \\
\text { tats, movements, and key population } \\
\text { dynamic processes of targeted fish } \\
\text { species. Fishing impact is simulated } \\
\text { through catch and effort data. A sta- } \\
\text { tistical optimization approach uses } \\
\text { all available data (catch by size, tag- } \\
\text { ging data, larvae density, acoustic } \\
\text { estimates) to estimate model param- } \\
\text { eters. }\end{array}$ & $\begin{array}{l}\text { Flexible; typically } \\
1 / 12^{\circ} \text { grid and daily } \\
\text { timestep, or } 1-2^{\circ} \\
\text { grid } \times \text { monthly time step. } \\
\text { Three vertical layers of } \\
\text { epipelagic and mesopelagic } \\
\text { ocean. }\end{array}$ & $\begin{array}{l}\text { One zooplankton and sev- } \\
\text { eral micronekton functional } \\
\text { groups defined based on } \\
\text { their vertical behaviour } \\
\text { and one to several targeted } \\
\text { species with their fisheries. }\end{array}$ & $\begin{array}{l}\text { Lehodey et } \\
\text { al. }(2008,2010)\end{array}$ \\
\hline APECOSM & $\begin{array}{l}\text { A 3-D dynamic energy budget- } \\
\text { based Eulerian model of size- } \\
\text { structured marine populations } \\
\text { and communities based on } \\
\text { environmentally driven individual } \\
\text { bio-energetics, trophic interactions, } \\
\text { and behaviours that are upscaled to } \\
\text { populations and communities. }\end{array}$ & $\begin{array}{l}\text { Regional or } \\
\text { global }\end{array}$ & $\begin{array}{l}\text { Includes light- and temperature- } \\
\text { driven size-based predation, food- } \\
\text { and temperature-driven growth, re- } \\
\text { production and senescence, and the } \\
\text { impact of the environment on ver- } \\
\text { tical and horizontal movements and } \\
\text { schooling. }\end{array}$ & $\begin{array}{l}\text { Can be run on any 3-D spa- } \\
\text { tial grid from regional to } \\
\text { global scale, with a daily } \\
\text { timestep distinguishing day } \\
\text { and night; no vertical res- } \\
\text { olution but vertical move- } \\
\text { ments explicitly parameter- } \\
\text { ized. }\end{array}$ & $\begin{array}{l}\text { Generic size-based commu- } \\
\text { nities are explicit (typically } \\
\text { epipelagic, migratory, } \\
\text { mesopelagic, and bathy- } \\
\text { pelagic) and focus } \\
\text { species. }\end{array}$ & Maury (2010) \\
\hline Madingley & $\begin{array}{l}\text { A global, mechanistic, spatially ex- } \\
\text { plicit "general ecosystem model" of } \\
\text { terrestrial and marine ecosystems } \\
\text { used to explore changes in } \\
\text { ecosystem structure and function. }\end{array}$ & $\begin{array}{l}\text { Regional or } \\
\text { global }\end{array}$ & $\begin{array}{l}\text { Models functional groups and } \\
\text { multispecies "cohorts"; millions of } \\
\text { cohorts in model. Includes spatially } \\
\text { explicit dispersal driven by ESM } \\
\text { outputs, food-dependent growth, } \\
\text { starvation, and senescence mortal- } \\
\text { ity. Allows for complete extinction } \\
\text { of functional groups, and dynamic } \\
\text { changes in ecosystem structure. } \\
\text { Food web links are dynamic; } \\
\text { cohorts can be prey or predator } \\
\text { depending on size. Unlike many } \\
\text { models, is not "mass balanced". } \\
\text { Predators can switch between prey } \\
\text { groups based on densities and } \\
\text { preferences. }\end{array}$ & $\begin{array}{l}\text { Any (typically } 1-2^{\circ} \text { and } \\
\text { monthly), with no vertical } \\
\text { resolution at present }\end{array}$ & $\begin{array}{l}\text { All (marine and terrestrial), } \\
\text { excluding microbes, mod- } \\
\text { elled as functional groups. }\end{array}$ & $\begin{array}{l}\text { Harfoot et } \\
\text { al. (2014) }\end{array}$ \\
\hline
\end{tabular}

included (Table 3). These variables are used on the spatial, temporal, and vertical scale appropriate to each model, but with a minimum monthly time step; e.g. models with a daily time step had to use monthly forcing data, taking the average value for that month and applying it daily (without the day-to-day variability typical of finer-scale forcing). This pri- marily reflects the limitations imposed by the available ESM output.

Across the diversity of participating models, we recognize four broad classes: those focusing on species distribution, trophodynamic structure, size- or age-based structure, and composite (hybrid) models. This simple classification is 
Table 2. Selected Earth system model outputs that are required or optional for individual Fish-MIP models. Fish-MIP models can require surface values, a mean or summed surface layer value (e.g. top $100 \mathrm{~m}$ ), surface and sea-floor values, or fully three-dimensional values. Note that this list is correct at the time of writing, but that models are continuously in development with new components and requirements being added. Units follow CMIP5 standard output (http://cmip-pcmdi.llnl.gov/cmip5/data_description.html).

\begin{tabular}{|c|c|c|c|c|c|c|c|c|c|c|c|c|}
\hline & \multicolumn{7}{|c|}{$\begin{array}{l}\text { Common variables used by at } \\
\text { least } 50 \% \text { of Fish-MIP models } \\
\text { (provided for all Fish-MIP simulations) }\end{array}$} & \multicolumn{5}{|c|}{$\begin{array}{l}\text { Selected variables } \\
\text { used by a small } \\
\text { proportion of models }\end{array}$} \\
\hline & 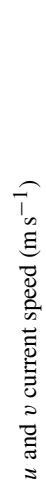 & 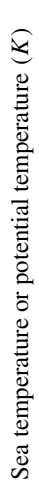 & 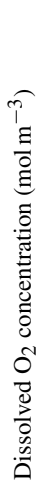 & 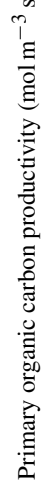 & 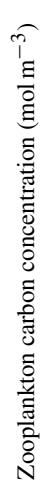 & 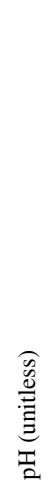 & 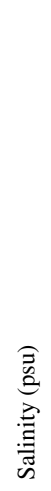 & 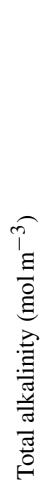 & 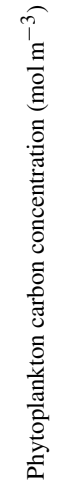 & 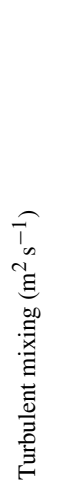 & 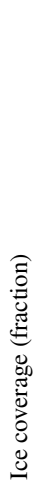 & 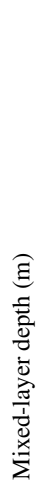 \\
\hline DBEM & $\bullet$ & $\bullet$ & $\bullet$ & & $\bullet$ & - & $\bullet$ & & & & $\bullet$ & \\
\hline SS-DBEM & $\bullet$ & $\bullet$ & $\bullet$ & $\bullet$ & & $\bullet$ & $\bullet$ & & & & $\bullet$ & $(\bullet)$ \\
\hline Ecopath With Ecosim & $(\bullet)$ & $(\bullet)$ & $(\bullet)$ & $\bullet$ & $\bullet$ & $(\bullet)$ & $(\bullet)$ & & $\bullet$ & & & \\
\hline EcoOcean & $(\bullet)$ & $\bullet$ & $(\bullet)$ & $\bullet$ & $(\bullet)$ & $(\bullet)$ & $(\bullet)$ & & $\bullet$ & & $(\bullet)$ & \\
\hline Macroecological model & & $\bullet$ & & $\bullet$ & $(\bullet)$ & & & & $(\bullet)$ & & & $\bullet$ \\
\hline DPBM & & $\bullet$ & & $(\bullet)$ & $(\bullet)$ & & & & $(\bullet)$ & & & $\bullet$ \\
\hline BOATS & & $\bullet$ & & $\bullet$ & & & & & & & & \\
\hline POEM & $\bullet$ & $\bullet$ & & & $\bullet$ & $\bullet$ & $\bullet$ & & & & $\bullet$ & $\bullet$ \\
\hline Atlantis & $\bullet$ & $\bullet$ & $\bullet$ & 2 & 1 & $\bullet$ & $\bullet$ & - & 2 & & & \\
\hline OSMOSE & & $\bullet$ & $\bullet$ & $\bullet$ &.$^{3}$ & & $\bullet$ & & $\bullet^{3}$ & & & \\
\hline SEAPODYM & $\bullet$ & $\bullet$ & $\bullet$ & $\bullet$ & & & & & $\bullet$ & & & \\
\hline APECOSM & $\bullet$ & - & $\bullet$ & & $\cdot^{3}$ & $\bullet$ & & & $\bullet^{3}$ & $(\bullet)$ & & \\
\hline Madingley & - & - & & • & 1 & & - & & & & & \\
\hline
\end{tabular}

- Used by model. (•) Can optionally be used by model. ${ }^{1}$ Not used for forcing, but can be used for cross-validation. ${ }^{2}$ Not used directly, but in combination with hydrodynamic flows is used to set boundary conditions and sub-grid-scale processes to allow for similar primary productivity shifts as in ESM outputs to be realized. ${ }^{3}$ Separated into large and small size classes.

used to structure this summary of models contributing to the Fish-MIP project.

\subsubsection{Model classes: species distribution based models}

Species distribution models (Cheung et al., 2016b; Fernandes et al., 2013; Jones and Cheung, 2015; Pearson and Dawson, 2003) use statistical, empirical, and theoretical relationships between a species and its environment to explore the implications of shifting environmental conditions and resulting habitat suitability distributions on the biomass and spatial range of species. Recent development has integrated this class of models with a mechanistic representation of ecophysiology and population dynamics and hence potential fisheries production (Cheung et al., 2011; Fernandes et al., 2013) and fishing scenarios (Fernandes et al., 2016, 2017). For instance, the Dynamic Bioclimate Envelope Model (DBEM; Table 1) was applied to a suite of over 1000 species to examine shifts in distribution, abundance, and productivity under climate change scenarios and resultant global patterns of local extinction, invasion, biodiversity, and catch (Cheung et al., 2016b; Jones and Cheung, 2015). A version of DBEM that has incorporated size-based trophodynamics to mimic ecological interactions has also been applied to model a number of ecosystems (Fernandes et al., 2013, 2016, 2017). Typically, this class of models includes a large number of primarily commercially valuable fishes and invertebrates. 
Table 3. Forcing variables derived from Earth system models and provided as input for global and regional marine fisheries models. Names and units follow CMIP5 standard output (https://cmip.llnl.gov/cmip5/data_description.html).

\begin{tabular}{|c|c|c|c|c|}
\hline Variable & Name & $\begin{array}{l}\text { Unit (assuming } \\
\text { depth resolved) }\end{array}$ & Frequency & Comments \\
\hline$u$ current & uo & $\mathrm{ms}^{-1}$ & Monthly & \\
\hline$v$ current & vo & $\mathrm{ms}^{-1}$ & Monthly & \\
\hline Temperature & $t$ & $\mathrm{~K}$ & Monthly & \\
\hline $\begin{array}{l}\text { Dissolved oxygen } \\
\text { concentration }\end{array}$ & 02 & $\mathrm{~mol} \mathrm{~m}^{-3}$ & Monthly & \\
\hline $\begin{array}{l}\text { Primary organic carbon } \\
\text { productivity }\end{array}$ & intpp & $\mathrm{mol} \mathrm{m}^{-3} \mathrm{~s}^{-1}$ & Monthly & $\begin{array}{l}\text { Sum of primary productivity by all primary } \\
\text { producers (three groups - lphy, sphy, diaz - } \\
\text { for GFDL reanalysis and } \\
\text { GFDL-ESM2M, two groups - lphy, sphy - for } \\
\text { IPSL) }\end{array}$ \\
\hline $\begin{array}{l}\text { Phytoplankton carbon } \\
\text { concentration }\end{array}$ & phyc & $\mathrm{mol} \mathrm{m}^{-3}$ & Monthly & $\begin{array}{l}\text { Sum of small and large phytoplankton } \\
\text { (including diazotrophs) }\end{array}$ \\
\hline $\begin{array}{l}\text { Small phytoplankton } \\
\text { carbon concentration }\end{array}$ & sphyc & $\mathrm{mol} \mathrm{m}^{-3}$ & Monthly & Picophytoplankton and nanophytoplankton \\
\hline $\begin{array}{l}\text { Large phytoplankton } \\
\text { carbon concentration }\end{array}$ & lphyc & $\mathrm{mol} \mathrm{m}^{-3}$ & Monthly & Diatoms, large non-diatoms, and diazotrophs \\
\hline $\begin{array}{l}\text { Zooplankton carbon } \\
\text { concentration }\end{array}$ & zoo & $\mathrm{mol} \mathrm{m}^{-3}$ & Monthly & Sum of small and large zooplankton \\
\hline $\begin{array}{l}\text { Small (micro)zooplankton } \\
\text { carbon concentration }\end{array}$ & szoo & $\mathrm{mol} \mathrm{m}^{-3}$ & Monthly & $\begin{array}{l}\text { Post-diagnosed by normalizing to phytoplank- } \\
\text { ton where unavailable }\end{array}$ \\
\hline $\begin{array}{l}\text { Large (meso)zooplankton } \\
\text { carbon concentration }\end{array}$ & lzoo & $\mathrm{mol} \mathrm{m}^{-3}$ & Monthly & $\begin{array}{l}\text { Post-diagnosed by normalizing to phytoplank- } \\
\text { ton where unavailable }\end{array}$ \\
\hline $\mathrm{pH}$ & $\mathrm{ph}$ & unitless & Monthly & \\
\hline Salinity & so & psu & Monthly & \\
\hline
\end{tabular}

\subsubsection{Model classes: trophodynamic-based models}

Trophodynamic models are typically structured based on species interactions and the transfer of energy across trophic levels. Ecopath with Ecosim (EwE), one of the oldest and most widely used marine ecosystem modelling approaches (Christensen and Walters, 2004), focuses explicitly on trophodynamics, as does its global offshoot EcoOcean (Christensen et al., 2015). EwE has been extensively used to explore potential fisheries impacts on and management options for aquatic ecosystems, to assess the impact of other human activities and climate variability and change (Niiranen et al., 2013), and to analyse and compare ecosystem structural and functional traits (Colleter et al., 2015). More recent applications include cumulative human impacts, marine conservation, environmental impact assessments, and endto-end modelling (Coll et al., 2015). EwE models typically include demersal and pelagic species from primary producers up to top predators, both commercial and non-commercial. Ecospace, the spatial-temporal model run in Ecosim in conjunction with the food web and fisheries dynamics components, has been further developed to spatially derive the foraging capacity of individual species from physical, oceanographic, and environmental drivers such as depth, temperature bottom type, oxygen concentrations, and primary production (Christensen et al., 2014). This development, in combination with the recently added spatial-temporal framework module (Steenbeek et al., 2013), has bridged the gap between environmental envelope models and food web models (Christensen et al., 2014, 2015). EwE models are typically structured by species or functional groups and can also include the age- or size- based representation of species.

\subsubsection{Model classes: size- or age- based models}

Contemporary models in this class build on size-based conceptualizations of marine ecosystems (Boudreau et al., 1991; 
Dickie et al., 1987; Platt and Denman, 1978; Sheldon et al., 1972; Sheldon and Parsons, 1967) to characterize the flux of energy from primary producers to higher predators. Sizebased approaches are predicated on the substantial role of body size in structuring food webs, which results from the dominance of small primary producers, size-based predation, and ontogenetic increases in trophic level when many predators grow 5-6 orders of magnitude in body mass from egg to adult (Jennings et al., 2012). The size-based models with the lowest parameter demands rely on empirical relationships that link body mass, temperature, and biological rates to support parameterization (e.g. Benoît and Rochet, 2004; Blanchard et al., 2009; Borgmann, 1987; Jennings and Collingridge, 2015; Watson et al., 2015). More complex sizebased approaches describe some of the differences among species in a size-structured community by incorporating information on traits such as species maximum (asymptotic) size (e.g. Andersen and Beyer, 2006; Carozza et al., 2016; Pope et al., 2006). Life history theory can be used to estimate parameters such as size at maturity and reproductive output from maximum size. Other size- and species- based models may incorporate some species-specific information directly (Blanchard et al., 2014; Maury et al., 2007; Maury and Poggiale, 2013; Shin and Cury, 2004), but use general size-based relationships to describe other components of the system such as predator-prey relationships. As a variant of a size-based approach, time of development (i.e. age) to reach a critical life stage can be used to model the dynamics of species or functional groups (Lehodey et al., 2010). This approach can help to represent the effects of key environmental influences (e.g. temperature) in a different way. As well as being used for assessing the effects of fishing and environmental variation on marine ecosystems (e.g. Fu et al., 2013; Shin and Cury, 2004), size- or age-based ecosystem models have been used to underpin linked analyses of the effects of climate change on fisheries and society (Barange et al., 2014), including marine commodity trade (Mullon et al., 2016).

\subsubsection{Model classes: composite (hybrid) models}

The final class of models uses multiple formulation types to create representations of entire systems. Until recently, these models were distinct from other classes due to the breadth of processes covered; convergent evolution means that this is becoming less the case. Nevertheless, this class of models still tends to feature a broader set of ecological processes (including movement, feeding, reproduction, habitat use), the major biophysical drivers (e.g. temperature and salinity), a more complete food web, and often nutrient dynamics and cycles. This is achieved through composite (hybrid) end-toend approaches that bring together multiple modelling methods either by coupling component models (which may be from the classes above) or via direct integration in a single unified framework. They resolve the food web to at least functional group and in some cases the species level (or a mix of the two approaches). An example is Atlantis (Fulton et al., 2011), which uses a transport model to characterize three-dimensional current flows, a size-resolved biomass pool-based representation of the plankton food web, patch dynamic representation of demersal habitats, colonizationbased representation of bacterial groups, and a fully agestructured representation of the vertebrate groups. On top of this is an effort allocation, and fisheries management model, and an ability to capture biogeochemical processes.

Many of the composite models (e.g. OSMOSE; Travers et al., 2009) are age or size structured, allowing them to capture the size-based feeding and ontogenetic shifts found in the size-based approaches discussed above. Aspects of the size-based approach are also used to represent the bulk of the food web in some composite models such as for the midtrophic levels of SEAPODYM (Lehodey et al., 2008, 2010) and APECOSM (Maury, 2010), with more detailed elaboration applied to a subset of the system of particular interest (e.g. target species and higher trophic level species, such as tunas). Most composite (hybrid) process-based models have had a regional focus, in part due to data and computational requirements. An exception is the Madingley model (Harfoot et al., 2014), which although not designed specifically for fisheries (or indeed only marine) studies, can be applied to those questions nonetheless. It takes an agent- and processbased approach and by representing broad functional groups rather than individual species has somewhat mitigated computational constraints. As with the other classes of models there has been a broad range of motivations for the development of these types of models. Nevertheless, their most common uses to date have been to explore ecosystem dynamics (Harfoot et al., 2014; Travers-Trolet et al., 2014), consider fisheries management options (Fulton et al., 2014) and climate change scenarios (Lehodey et al., 2015), and test the performance of ecosystem indicators (Fulton et al., 2005; Travers et al., 2006).

\section{Forcing data: Earth system models and fisheries}

The fundamental goal of Fish-MIP is to compare the response of marine ecosystem models to common external forcings, including anthropogenic change. This is achieved by forcing the fisheries and marine ecosystem models with ocean hindcasts and scenario-driven projections from general circulation models (GCMs) that include coupled biogeochemistry modules. At present, this has been limited to global-scale ESMs following CMIP5 protocols, though in principle regional GCMs (e.g. using the ROMS framework) could also be used. For participating Fish-MIP models that allow it, the simulations also include spatially explicit estimates of fishing effort or catch. A completely standardized forcing cannot be used as the broad range of ecosystem models require different sets of inputs. Excluding all models ex- 
cept those with common inputs would have removed many well-established and widely used marine ecosystem models from the Fish-MIP project and substantially reduced the inclusivity and utility of the comparisons. Consequently, FishMIP decided to force all models with the specific inputs they needed, but to draw these from a consistent set of ESM simulations (subsampled at different spatial and temporal resolutions).

The first round of Fish-MIP was conducted with CMIP5 output, as detailed here. This is because model outputs from CMIP6 in formats suitable for marine ecosystem models were not available to the ISIMIP and Fish-MIP communities at the time the Fish-MIP v1.0 simulations were started. However, the Fish-MIP project has participated in the Vulnerability, Impacts, Adaptation and Climate Services (VIACS) advisory board for CMIP6 (Ruane et al., 2016), specifically to communicate the requirements for marine ecosystem models, in particular the need for archiving full three-dimensional depth-resolved monthly biogeochemical outputs. We therefore anticipate that CMIP6 output (Eyring et al., 2016) will be utilized in a future round of Fish-MIP (likely in ISIMIP phase 3, planned for the end of 2018) and in addition that the number of ESMs providing suitable forcings to Fish-MIP models will increase.

\subsection{Environmental drivers from Earth system models}

We reviewed the 10 CMIP5 models considered by Bopp et al. (2013) that included projections for a suite of potential physical and biogeochemical stressors (warming, deoxygenation, acidification, and changes in ocean productivity). The models we determined suitable for Fish-MIP were GFDL-ESM2M and IPSL-CM5A-LR, with CESM1-BGC also likely to be incorporated in the future. Four key criteria were used to select ESM model outputs for use in Fish-MIP.

Availability. At minimum, representative concentration pathway (RCP) simulations with lowest and highest impact scenarios (RCPs 2.6 and 8.5) to 2099 are available and accessible, and ideally RCPs 4.5 and 6.0 as well. Historical runs are available from at least 1960. All physical and biogeochemical oceanic forcing fields needed to drive all the Fish-MIP marine ecosystem models (i.e. all "common" variables listed in Table 2) are ideally available at 3-D spatial and monthly mean temporal resolution.

Quality control. ESMs vary widely in the complexity of their biogeochemical formulations, with some including minimalist representations aimed at the efficient representation of carbon cycling and others featuring more resolved representations of plankton dynamics aimed at both biogeochemical and marine resource applications. While the ESMs are robustly correlated with SST, oxygen, $\mathrm{CO}_{2}$, and 3 -D-resolved $\mathrm{pH}$, they vary widely in their correlation with satellite-based NPP estimates (Bopp et al., 2013), likely in large part a result of differences in the scope of objectives.
Globally, we did not select models for which the correlation coefficient $(r)$ with NPP fell below 0.4 .

Future response. The selected ESMs spanned a significant fraction of the cross-ESM range in the future projections of physical and biogeochemical fields, especially in primary production and plankton biomasses. This allows the FishMIP models to be tested across a wide range of plausible future scenarios. In this regard, IPSL-CM5A-LR features a relatively strong surface warming and global NPP decline, GFDL-ESM2M has relatively small changes, and CESM1BGC, though not incorporated in the first round of model runs, is an intermediate case.

Model drift. The model drift of the ESM outputs, as diagnosed from the control simulation (i.e. no climate forcing), is negligible.

Interestingly, the "availability" criterion imposed the greatest limitation on the choice of ESMs. Of the more than 30 ESMs participating in CMIP5, only a subset (10) included necessary marine biogeochemical ocean model components (temperature, $\mathrm{pH}$, dissolved oxygen, and NPP; Bopp et al., 2013). Furthermore, only one model (IPSL-CM5A-LR) currently produces the full set of ESM outputs required to drive all marine ecosystem models included in the Fish-MIP project (i.e. met the full "availability" criterion and had full three-dimensional depth-resolved monthly data). Many modelling groups at the time of protocol development had either not uploaded their full biogeochemical fields to the CMIP5 Earth System Grid Federation (ESGF) archive or did not output the variables at the full 3-D spatial and monthly time resolution required by some Fish-MIP marine ecosystem models, possibly due to a lack of time and/or funding. As a result, ESM modelling groups were approached individually to obtain access to the full biogeochemical fields at the required temporal and spatial resolution. "Quality control" also eliminated several models from our ESM selection. Since ESMs have not been specifically designed to force ecosystem models, some outputs such as planktonic biomass and productivity may have spurious or unrealistic values for some regions and/or depths and needed to be checked before use. Although "availability" and "quality control" mostly acted to limit our ESM selection, fortuitously the models selected for these attributes also span a range of potential "future response" trajectories in ocean temperature, NPP, dissolved oxygen, and pH (Bopp et al., 2013). For ease of use, all data were converted into the same units and re-gridded onto a common $1 \times 1^{\circ}$ grid. For examples of ESM forcing data see Figs. S1 and S2 in the Supplement.

The number and type of phytoplankton and zooplankton groups represented in ESMs vary substantially (Bopp et al., 2013) and an explicit differentiation into large and small planktonic groups, as needed by some of the ecosystem models, was not always available. For the purpose of forcing Fish-MIP models, "large" and "small" phytoplankton groups were defined in such instances. In the ESM outputs, we defined the large phytoplankton functional group (lphy) to in- 
clude diatoms, large non-diatoms, and the diazotrophs; although small diazotrophs exist, it was generally not possible to separate them out, and ESMs tend to parameterize diazotrophs as larger, Trichodesmium-like organisms (Capone et al., 1997). Primary production associated with nitrogen fixation is much less than total primary production (Gruber and Galloway, 2008), allaying concerns over this simplification. The small phytoplankton group (sphy) included the picophytoplankton and nanophytoplankton groups. Only the IPSL-CM5A model explicitly represented size-differentiated zooplankton groups (szoo and 1zoo). For other ESMs for which these were unavailable, the zooplankton size classes were post-diagnosed by normalizing to phytoplankton biomass such that $1 z o o=$ zoo $\times$ lphy $/($ sphy + lphy $)$ and szoo $=$ zoo $\times$ sphy $/($ sphy + lphy $)$. This simple approach makes the assumption that the small zooplankton and large zooplankton biomass residence times are the same.

For the first round of Fish-MIP, all modellers were encouraged to force their models with the ESM inputs that made sense biologically and ecologically, as determined by the mechanisms and assumptions specific to individual models (the "optimized" simulation), enabling us to examine outputs based on ideal (from the perspective of the individual marine ecosystem model) forcings. For subsequent rounds, we will also specify a "standardized" ESM input simulation to better distinguish differences in marine ecosystem model outputs due to ESM forcings from those due to ecosystem model structure. As an example, some modelling groups preferred to remove the diazotroph contribution from their primary productivity or planktonic biomass input fields because it was assumed that this material is not efficiently transferred up the food chain. Removing the diazotrophs is the "optimized" simulation, while the "standardized" simulation would include the diazotrophs in the biomass and primary productivity input fields.

\section{Downscaling to regional domains}

Fish-MIP aims to compare temporal and spatial outputs between global and regional models. Output from global models can be subsampled over the areas considered by regional models, such as the North Sea, and the regional models can be forced with ESM output averaged over the grid cells included in the regional model domain. In this way, the global and regional model responses to common environmental variations can be directly compared. Regional marine ecosystem models often have highly resolved survey, stock assessment, and/or fishing effort data as inputs, and therefore this direct comparison can help to test and contextualize biases in the global models. Furthermore, regional marine ecosystem models have often been previously integrated with higher-resolution ocean and biogeochemical simulations, providing comparisons with resolution of fine-scale structure in space and time.
At this point in ESM development, it is important to note that regional downscaling remains problematic. The ESMs in CMIP5 have ocean resolutions of $\sim 1-2^{\circ}$ and are thus only capable of resolving circulation features on the order of $300 \mathrm{~km}$ or larger. This leads to a limited representation of coastal ocean and marginal sea currents and upwelling and, in some cases, substantial regional biases in ecosystem drivers (Holt et al., 2016; Stock et al., 2011). In addition, ESMs struggle to represent iron limitation well (Tagliabue et al., 2015), which can add an additional potential source of bias, especially when simulating primary production in ironlimited ecosystems such as the Southern Ocean (Moore et al., 2013) or sub-Arctic Pacific. They also struggle to represent the extent of tropical oxygen minimum zones (Cabré et al., 2015), which represents a limitation for marine ecosystem models using dissolved $\mathrm{O}_{2}$ as an input variable. More generally, confidence in climate change projections is greatest at continental scales and above (Randall et al., 2007). Thus, while the Fish-MIP protocol is developed to enable the consideration of both global and regional applications, the limitations of present tools suggest an emphasis on forecasted large-scale changes (e.g. shifting and evolving ocean biomes, latitudinal contrasts) coupled with a more cautious consideration of the regional implications of large-scale drivers (such as $\mathrm{CO}_{2}$ ) resolved by ESMs.

To date, some regional ecosystem models have used the downscaling of global-scale model outputs or highresolution shelf seas models (Barange et al., 2014; Stock et al., 2011). The concerted development of high-resolution global climate and Earth system models with improved resolution of coastal processes (e.g. Saba et al., 2016) should ease this limitation moving forward. Alternatively, growing suites of regionally downscaled solutions (e.g. Holt et al., 2016) may provide a basis for region-specific implementations of the Fish-MIP protocol. Although it is likely that these biases will be reduced over the coming years and decades, they must be borne in mind as inescapable shortcomings of the current state-of-the-art in ESM models.

\subsection{Fishing scenarios}

Fishing is an important human driver of changes in marine ecosystems and is represented in most marine ecosystem models as a spatially and temporally varying term that removes biomass and production from the system. This term is typically applied in one of two ways within marine ecosystem models. It can be imposed as a biomass removal rate per unit of time based on empirical or modelled catches (or landings) and removed directly from the system biomass for specific functional groups, ages, and size classes. Alternatively, it can be applied as a mortality rate, which removes a fraction of the existing biomass per unit of time. This mortality rate can be applied directly or calculated from a fishing effort term which considers both "nominal effort" (total resources devoted to fishing) and the catchability of fish to give 
an "effective" fishing effort (Jennings et al., 2001). Nominal effort reflects human involvement in fishing (e.g. number and engine power of fishing boats and time spent fishing). Catchability, defined as the proportion of biomass that can be caught per unit of fishing effort, can be affected by both ecological and human factors. For example, the aggregation behaviour of some fish stocks can increase their catchability (Arreguin-Sanchez, 1996). Improvements in fishing technology or changes in gear configuration (e.g. changes in the mesh size of nets) can also affect catchability.

There are important differences between models forced with catch and those forced with effort that make the consistent representation of fisheries impacts in the Fish-MIP project challenging when bringing such disparate approaches together. Models forced with catch can drive ecosystem components extinct if the forced catches are incompatible with biomass dynamics and can be used to see if observed historical catches can be maintained given model dynamics. Models forced with effort or mortality produce emergent catches derived from available modelled biomass. These catches can be compared to historically observed data to assess confidence in the model's forcing and ability to reproduce observations. Fish-MIP models also vary in the complexity and degree of linkages and feedbacks to other biophysical and human components of the ecosystems that they represent. In some models, fishing effort, catch, or mortality rates are parameters or forcing variables with no feedback from the biological systems to the socio-economic systems. However, some hybrid and trophodynamic models fully couple these systems.

Individual Fish-MIP models use various data sources for their fisheries impact forcing, which reflects variation in model purpose, development history, functional group representation, spatial scale and resolution, inclusion of illegal, unregulated, and unreported (IUU) fisheries, and other factors. Modelled fishing mortality rates, catches, or effort can vary over time and space and can be spatially explicit or applied at local, regional, or basin scales. Most databases on global fishing catch or effort can be spatially disaggregated to match the scales represented in (global) marine ecosystem models. The difference between such data sources may be considerable; see Fig. S3 for an example of the difference in global catches over time between two databases.

As examples of approaches taken by individual FishMIP models, the EcoOcean model applies fishing as an effort term based on the Sea Around Us Project (SAUP) effort database (Anticamara et al., 2011; Christensen et al., 2015; Watson et al., 2013), the DBEM model uses an alternate catch reconstruction database (Watson, 2017), BOATS has a dynamic bioeconomic approach using SAUP catch price data to simulate spatially resolved changes in fishing effort over time based on individual fishers attempting to optimize their outcomes (Carozza et al., 2017), and SS-DBEM represents maximum sustainable yield without explicitly calculating fishing mortality (Fernandes et al., 2016, 2017; Mullon et al., 2016) using SAUP data supplemented by other sources (the ICES data collections at www.ices.dk/marine-data/dataset-collections/Pages/ Fish-catch-and-stock-assessment.aspx and the RAM legacy stock assessment database at www.ramlegacy.org). This last example further demonstrates how fishing impacts may be modelled implicitly. Regional models have typically used yet different data sources, which are often finely resolved observer-derived local datasets with highly taxonomically resolved information.

In the first round of Fish-MIP, to maximize the participation of marine ecosystem models, we decided to allow models to implement fishing according to their own standard method to produce realistic historical transients, followed by constant fishing impacts for future scenarios. That is, models continued to use their specific catch, effort, or other forcing data (often but not always SAUP data for global models), but with simple standardized scenarios imposed.

For historical simulations (to 2005), biomass removal based on reported catches or historical effort levels was imposed to reconstruct the historical level of fishing (Christensen et al., 2015) or assumptions were made about average fishing mortality in historical periods (Cheung et al., 2016b). As above, this was based on each Fish-MIP model's specified fishing database. In addition to the standardized scenario, an optional scenario was suggested with no fishing (zero effort or mortality or fisheries-induced). Some models included no representation of fishing and thus only ran this optional scenario of zero fishing. For future projection simulations, in the current absence of operationalized spatially explicit scenarios of effort or catch, the standardized model run was to keep fishing constant at 2005 rates (from their specified data source), while the optional scenario was again zero fishing. Our scenarios therefore imposed a fishing impact (in fished model runs) while maintaining consistency among each model's fit to historical data. Given the simplicity of this approach, we focus on climate impacts for FishMIP 1.0 and plan to explore the impacts of fishing in more detail following the development of specified future fisheries scenarios.

Improving the inter-model consistency of fisheries forcings remains a substantial challenge for the marine ecosystem modelling community. In subsequent iterations of FishMIP, we will aim to reconcile the various historical input data streams to further quantify their effects on results and, if possible, further standardize prescribed input sources. Developing more sophisticated future scenarios of fisheries remains challenging. Formally developed global qualitative storylines depicting future fishing activity, management, and technological change are beginning to be designed (e.g. Maury et al., 2017), but need to be "operationalized" in terms of translating them into a spatially and temporally explicit form to enable them to force marine ecosystem models. The development of such global projections of fishing pressure over the 21 st century will be necessary to better understand the consequences of interactions between climate and fisheries effects 
Table 4. Selected outputs produced by individual models. Note that this list is correct at the time of printing, but that models are continuously in development with new components and requirements being added. This table lists a range of potential outputs from models participating in Fish-MIP; for the list of requested and optional model outputs, see Table 5.

\begin{tabular}{|c|c|c|c|c|c|c|c|c|c|c|c|}
\hline & \multicolumn{8}{|c|}{$\begin{array}{c}\text { Common outputs } \\
\text { produced by at } \\
\text { least } 50 \% \text { of models }\end{array}$} & \multicolumn{3}{|c|}{$\begin{array}{l}\text { Optional outputs } \\
\text { produced by a small } \\
\text { proportion of models }\end{array}$} \\
\hline & 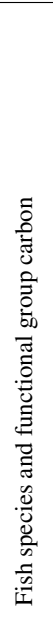 & 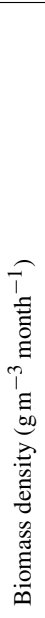 & 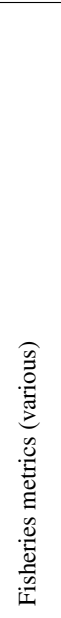 & 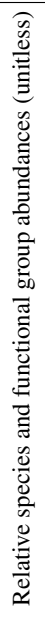 & 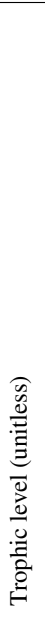 & 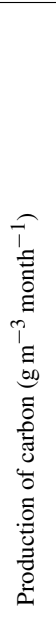 & 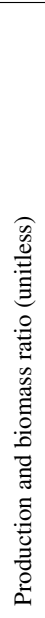 & 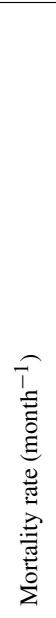 & 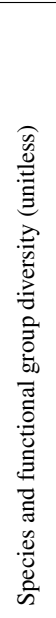 & 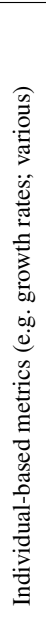 & 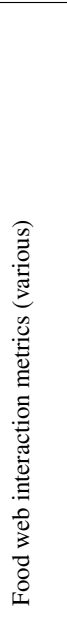 \\
\hline DBEM & & & $\cdot 4$ & - & & & & & & & \\
\hline SS-DEBM & & $\bullet 1$ & .5 & • & & & & & & & \\
\hline Ecopath with Ecosim & & $\bullet$ &.$^{6}$ & $\bullet$ & $\bullet$ & $\bullet$ & • & $\bullet$ & • & & $\bullet$ \\
\hline EcoOcean & & $\bullet$ & .7 & $\bullet$ & - & $\bullet$ & $\bullet$ & $\bullet$ & $\bullet$ & & $\bullet$ \\
\hline Macroecological model & & $\bullet$ & & & $\bullet$ & $\bullet$ & $\bullet$ & $\bullet$ & & & \\
\hline DPBM & & .1 & $\bullet 6,8$ & $\bullet$ & $\bullet$ & - & - & - & & $\bullet$ & $\bullet$ \\
\hline BOATS & & .1 & .6 & & - & $\bullet$ & - & - & & $\bullet$ & \\
\hline POEM & & $\bullet$ & & & & $\bullet$ & & & & & \\
\hline Atlantis & & - & .6 & $\bullet$ & - & $\bullet$ & $\bullet$ & - & $\bullet$ & - & $\bullet$ \\
\hline OSMOSE & & - & .6 & - & - & $\bullet$ & $\bullet$ & - & $\bullet$ & $\bullet$ & $\bullet$ \\
\hline SEAPODYM & &.$^{2}$ & $\bullet^{9}$ & & & $\bullet$ & - & - & & & \\
\hline APECOSM & &.$^{3}$ & .10 & & - & & & - &.$^{10}$ & $\bullet$ & \\
\hline Madingley & & - & & $\bullet$ & $\bullet$ & & & $\bullet$ & - & - & $\bullet$ \\
\hline
\end{tabular}

${ }^{1}$ As a size spectrum. ${ }^{2}$ Tunas and associated species; age structured. ${ }^{3}$ Size spectrum for epipelagic, migratory, mesopelagic, and bathypelagic communities, together with focus species (e.g. tunas). ${ }^{4}$ Relative functional group abundances. ${ }^{5}$ Catch rates. ${ }^{6}$ Catch and fishing mortality. ${ }^{7}$ Seafood production. ${ }^{8}$ Potential catch. ${ }^{9}$ Catch and size frequency for tunas. ${ }^{10}$ Commercial landings.

on ecosystems and resultant yields. Deriving projections that recognize the complexities of fisheries management remains particularly challenging, even at regional scales which may more naturally map to specific existing management units. Such projections would need to account for the significance of many drivers and feedbacks which influence mortality rates and the catches that result. These include economic drivers of fleet capacity, effort, and distribution; environmental and fisheries policies and associated management targets, the extent to which targets are met and their responsiveness to changes in the environment, fisheries, and society; the selectivity and efficiency of fishing operations; fishery and species interactions; and external modifiers of demand for and access to wild fish for food (e.g. growth of aquaculture, marine conservation, certification, ethics). A further challenge is to develop comparable projections for different fish production models, for example with appropriate assumptions necessary to translate between species- and size-based projections of mortality and selection. The underlying difficulty with developing all such projections is that yield is not a stable construct, but changes dynamically in relation to the species and sizes targeted, with feedbacks, and with the evolution of the fished ecosystem. When future fishing scenarios do become operationalized, they will be used to replace the standardized run with constant 2005 catch or effort in future model experiment protocols. 
Table 5. Common output variables to be provided by global and regional marine fisheries models.

\begin{tabular}{|c|c|c|c|c|}
\hline Output variable & $\begin{array}{l}\text { Variable } \\
\text { name }\end{array}$ & $\begin{array}{l}\text { Temporal } \\
\text { resolution }\end{array}$ & Unit & Comments \\
\hline Total system carbon biomass & tsb & Monthly & $\mathrm{g} \mathrm{m}^{-2}$ & $\begin{array}{l}\text { All primary producers and } \\
\text { consumers }\end{array}$ \\
\hline $\begin{array}{l}\text { Total consumer carbon biomass } \\
\text { density }\end{array}$ & $\mathrm{tcb}$ & Monthly & $\mathrm{g} \mathrm{m}^{-2}$ & $\begin{array}{l}\text { All consumers (trophic level }>1 \text {, } \\
\text { vertebrates and invertebrates) }\end{array}$ \\
\hline $\begin{array}{l}\text { Carbon biomass density of } \\
\text { consumers }>10 \mathrm{~cm}\end{array}$ & b10 & Monthly & $\mathrm{g} \mathrm{m}^{-2}$ & $\begin{array}{l}\text { If asymptotic length }\left(L_{\mathrm{inf}}\right) \text { is } \\
>10 \mathrm{~cm} \text {, include in }>10 \mathrm{~cm} \text { class }\end{array}$ \\
\hline $\begin{array}{l}\text { Carbon biomass density of } \\
\text { consumers }>30 \mathrm{~cm}\end{array}$ & b30 & Monthly & $\mathrm{g} \mathrm{m}^{-2}$ & $\begin{array}{l}\text { If asymptotic length }\left(L_{\mathrm{inf}}\right) \text { is } \\
>30 \mathrm{~cm} \text {, include in }>30 \mathrm{~cm} \text { class }\end{array}$ \\
\hline $\begin{array}{l}\text { Total catch (all commercial } \\
\text { functional groups or size classes) }\end{array}$ & tc & Monthly & $\mathrm{g}$ wet biomass $\mathrm{m}^{-2}$ & $\begin{array}{l}\text { Catch at sea (commercial landings } \\
\text { plus discards), fish and inverte- } \\
\text { brates; fished runs only }\end{array}$ \\
\hline $\begin{array}{l}\text { Total landings (all commercial } \\
\text { functional groups or size classes) }\end{array}$ & tla & Monthly & $\mathrm{g}$ wet biomass $\mathrm{m}^{-2}$ & $\begin{array}{l}\text { Commercial landings (catch with- } \\
\text { out discards), fish and invertebrates; } \\
\text { fished runs only }\end{array}$ \\
\hline
\end{tabular}

\section{Output data}

The broad range of marine ecosystem and fisheries models (Sect. 2) leads to an equally broad range of potential model outputs (Table 4). To compare outputs from Fish-MIP models, we selected six common output variables that most models would be able to produce (total system biomass, total consumer biomass, biomass of consumers $>10$ and $>30 \mathrm{~cm}$, and, for models forced by fishing effort, catches and landings; see Table 5). We also developed a list of additional optional outputs that some models are capable of producing (e.g. biomass and catch of individual species or trophic group); see Table S1. This dual approach was adopted to achieve a balance between having common outputs that all models could produce and producing comparisons across as broad an array of outputs as possible. Some output variables were not native to individual models (such as biomass by size classes) and required post-processing; however, this appeared to be the only way to compare the outputs of size-based models with those from species- or trophic-group-structured models.

Some models output biological state variables (e.g. biomass) as wet weight and some as carbon, so different factors were used when converting from one to the other, sometimes differing between functional groups. Another issue is the conversion of biomass density to or from size classes, functional groups, and species. There appeared to be no universal approach that was meaningful across all ecosystem model types, so we settled on model outputs for all sizes, as well as size bins of maximum length $>10$ and $>30 \mathrm{~cm}$. This meant that mass-length conversions were handled differently in different models. All of these details matter when we are seeking to develop effective and informative compar- isons and were not all readily documented or accessible at the outset. However, our comments should not be taken to imply that every detail needs to be harmonized among models; in fact, for equitable comparison, it may be desirable to retain much of the diversity of model specifications. In any case, carefully specified information must be shared on those aspects that are harmonized - be it variable names and definitions, scenarios, or datasets - and those aspects that necessarily remain idiosyncratic. For example, 3-D models can use oceanic depth profiles that differ from ESM outputs. Ultimately, modellers used their specific depth profile and we accepted this as a potential confounding factor (in the same way as having 2-D and 3-D models). Another important contrast is the inclusivity of the species represented, which in some cases is all species (e.g. macroecological model), in others all commercial species (e.g. BOATS), and in others only a subset of commercial species (e.g. SEAPODYM). Thus, at this point, for quantities such as fish catch the relative trends can be compared readily between models and observations, but the absolute values need to be considered carefully.

It was agreed that output data should be depth column integrated on a $1 \times 1^{\circ}$ grid at a monthly (where possible) resolution, with "no data" values set to $1.0 \mathrm{e}+20 \mathrm{f}$ and variable names as in Table 5. Time series requested were 1971 to 2004-2005 (depending on ESM forcing) for historical models runs and 2006-2099 for future scenarios. For an example of model output, see Fig. S4. All files were to be saved in netcdf format with a .nc4 extension (a conversion script for .csv files was made available at http://vre2.dkrz.de). Full details on outputs, including the conventions for file naming, were made available in the ISIMIP 2A simulation protocol at https://www.isimip.org/protocol/\#isimip2a, and the instruc- 
Table 6. All experiments (historical and future, standardized, and optional) for the global and regional fisheries and marine ecosystem models participating in the first round of Fish-MIP. Runs in bold are prioritized (Tier 1), those in roman preferred but optional (Tier 2), and those in italics optional (Tier 3); this is to allow modellers with limited computational resources to participate and prioritize. Note that the CMIP5-based runs (non-reanalysis) are continuous from historical into the future, reducing the total number of runs.

\begin{tabular}{|c|c|c|c|c|c|}
\hline $\begin{array}{l}\text { Earth system } \\
\text { model forcing }\end{array}$ & Scenario & Time period & Fishing effort & Ocean acidification & No. of runs \\
\hline $\begin{array}{l}\text { GFDL ESM2M } \\
\text { (reanalysis) }\end{array}$ & historical & $1971-2005$ & $\begin{array}{l}\text { unfished (zero effort or mortality) } \\
\text { time-varying effort or mortality }\end{array}$ & default (time-varying $\mathrm{pH}$ ) & 2 \\
\hline $\begin{array}{l}\text { IPSL-CM5A- } \\
\text { LR }\end{array}$ & historical & $1971-2005$ & $\begin{array}{l}\text { unfished (zero effort or mortality) } \\
\text { time-varying effort or mortality }\end{array}$ & default (time-varying $\mathrm{pH}$ ) & 2 \\
\hline GFDL ESM2M & historical & $1971-2005$ & $\begin{array}{l}\text { unfished (zero effort or mortality) } \\
\text { time-varying effort or mortality }\end{array}$ & default (time-varying $\mathrm{pH}$ ) & 2 \\
\hline $\begin{array}{l}\text { IPSL-CM5A- } \\
\text { LR }\end{array}$ & $\begin{array}{l}2.6 \\
(\mathrm{rcp} 2 \mathrm{p} 6) \\
8.5(\mathrm{rcp} 8 \mathrm{p} 5)\end{array}$ & 2006-2099 & $\begin{array}{l}\text { unfished (zero effort or mortality) } \\
\text { keep constant at } 2005 \text { levels }\end{array}$ & default (time-varying $\mathrm{pH}$ ) & 4 \\
\hline$I P S L-C M 5 A-L R$ & $\begin{array}{l}4.5 \\
(r c p 4 p 5) \\
6.0(r c p 6 p 0)\end{array}$ & 2006-2099 & $\begin{array}{l}\text { unfished (zero effort or mortality) } \\
\text { keep constant at } 2005 \text { levels }\end{array}$ & default (time-varying $\mathrm{pH}$ ) & 4 \\
\hline GFDL ESM2M & $\begin{array}{l}2.6 \\
(\mathrm{rcp} 2 \mathrm{p} 6) \\
8.5(\mathrm{rcp} 8 \mathrm{p} 5)\end{array}$ & 2006-2099 & $\begin{array}{l}\text { unfished (zero effort or mortality) } \\
\text { keep constant at } 2005 \text { levels }\end{array}$ & default (time-varying $\mathrm{pH}$ ) & 4 \\
\hline
\end{tabular}

tions are at https://www.isimip.org/protocol/isimip2b-files/ (see also the Supplement for this paper).

Commercial species were defined as all potentially harvested fish $>10 \mathrm{~cm}$. All modelling groups used their own size classes and functional groups when running the model and provided the name and definition of size classes and functional groups used for total catch and landings. For common standard equations and mass-length conversion, models that did not have their own conversions were referred to FishBase (www.fishbase.org). It was also requested that the conversion values from wet weight to carbon should be specified.

\section{Core simulations in the Fish-MIP v1.0 protocol}

As the first marine sector included within ISIMIP, the FishMIP protocol was developed to align with the aims and scope of the overall ISIMIP project and to harmonize forcing simulations and scenarios whenever feasible. However, we also needed to balance this approach with the need to allow the effective intercomparison of marine ecosystem models given currently available modelling platforms and forcing data (see previous Section) and to consider the relative roles of climate and fishing. For historical (hindcasting) model runs, we used a GFDL-reanalysis product (Cheung et al., 2013) as our common "observational" climate input set of time series (Table 6). For future projections, we used GFDL and IPSL products (see Sect. 3), with priority on the RCP 2.6 and 8.5 scenarios, to span a range of alternate futures (Table 6). Thus, it should be possible to compare the effects of a climate signal based on a given ESM across ecosystem models, with differences among models reflecting a combination of their sensitivities to different aspects of climate change linked to differences in model structure and parameterization (as well as any other differences in forcing variables).

Depending on the ecosystem model complexity, times required for a defined simulation can differ by orders of magnitude. We therefore decided on a multi-tier hierarchy of standardized and optional climate- and fisheries-forced simulations (see Table 6) that ensured we could do the following: (i) compare many marine ecosystem model outputs across a few top priority ESMs and reanalysis product historical runs; (ii) assess the spread of future projections by comparing outputs for at least one ESM (IPSL) across all four RCPs (2.6, $4.5,6.0,8.5)$, as well as for at least one RCP (8.5) across the selected ESMs; (iii) separate the climate from the fishing signal by including simulations with and without fishing in historical and future runs; (iv) and for regional models, separate the effect of running the model with local data (key run, which may use statistically downscaled inputs) compared to a data subset from a global ESM. The core simulations from the initial round are as follows.

Historical runs. For historical runs for both global and regional models, the top priority (Tier 1) was one run each with all the climate datasets (reanalysis based, CMIP5 based) with no fishing (zero effort or mortality) and ocean acidification (time-varying $\mathrm{pH}$ ). The lower priority (Tier 2) was to run the 
(a) Global models: IPSL RCP 8.5 without fishing

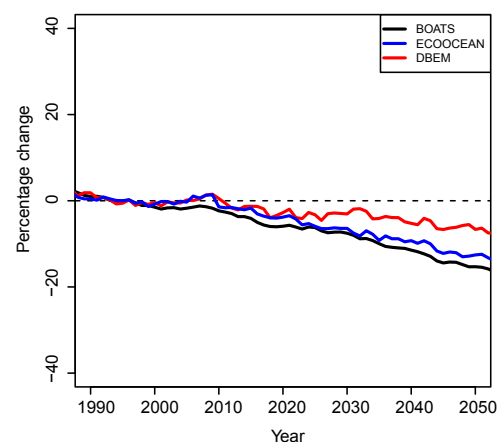

(b) Regional models: SE Australia without fishing

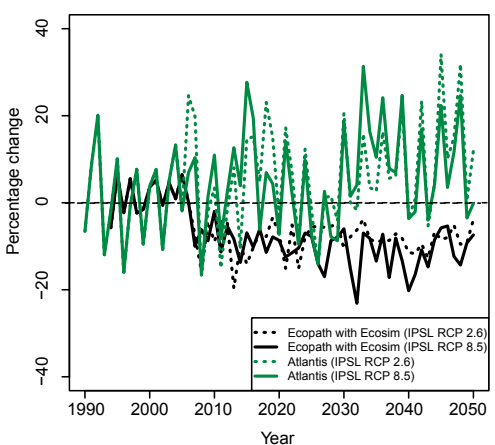

(c) Multi-model mean change in total consumer biomass IPSL RCP 8.5 without fishing: 1990s to 2050s

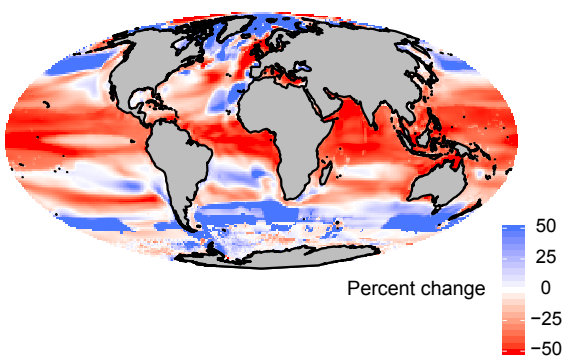

Figure 1. Example outputs from the Fish-MIP v1.0 protocol core simulations. (a) Global model time series output. Percentage change in global spatially averaged total consumer carbon biomass density $\left(\mathrm{g} \mathrm{m}^{-2}\right)$ from 1990 to 2050 . All values are relative to the $1990-1999$ mean. Values are shown for three marine ecosystem models: a size-based model (BOATS), a trophodynamic model (EcoOcean), and a species distribution model (DBEM). Output only shown for IPSL RCP 8.5 model runs without fishing imposed. For definition of total consumer carbon biomass, see Table 5. (b) Regional model time series output. Percentage change in spatially averaged total consumer carbon biomass density $\left(\mathrm{g} \mathrm{m}^{-2}\right)$ from 1990 to 2050. All values are relative to the 1990-1999 mean. Values are shown for two regional marine ecosystem models in southeast Australia: a trophodynamic model (Ecopath with Ecosim) and a composite (hybrid) model (Atlantis). The spatial extent of models is overlapping but non-identical. Output only shown for IPSL RCP 2.6 and IPSL RCP 8.5 model runs without fishing imposed. (c) Global spatial model output runs (models as per panel a) for IPSL RCP 8.5 with no fishing imposed. Ensemble model mean percentage change in total consumer carbon biomass density (originally in $\mathrm{g} \mathrm{m}^{-2}$ ) from the 1990 s to the 2050s; a positive value indicates an increase over time. Percentage changes in each grid cell for the three models in panel (a) over this time period were averaged.

same set of climate data with time-varying fishing effort or mortality (see Table 6).

Future runs. For future runs with both global and regional models, the top priority (Tier 1) was one run each with all the climate datasets (CMIP5 based) with no fishing (zero effort or mortality) and ocean acidification (time-varying $\mathrm{pH}$ ) for both the RCP 2.6 and 8.5 scenarios. The second priority (Tier 2) was to run the same set of climate data with default fishing effort or mortality (kept constant at 2005 levels) (see Table 6). The third priority (Tier 3 ) was the full set of experiments for RCP 4.5 and 6.0 scenarios where available (at present, only the IPSL-CM5A-LR model).

For all runs, it was requested that all non-specified external forcings (e.g. habitat modification) should be kept at default settings (time varying until 2005, constant at 2005 levels into the future). Input data were provided from 1951-1959 to 2004-2005, with a request that years until 1970 should be replicated as needed and used for spin-up (spin-up to be decided individually by each modelling group). Historical reporting was from 1971-2005 or whenever the model started if later.

Figure 1 shows example outputs from regional and global model runs for a subset of the Fish-MIP models. Note that results can be visualized either spatially or as time series, as absolute values or relative changes, and can be represented as individual simulation outputs for specific models, and/or averages across multiple models. While we refrain from discussing results and specific values as only a subset of models and simulations are shown here, we do note that there is substantial temporal variation in the magnitude and direction of trends between models and spatial variation in the ensemble model mean. Separate papers from the Fish-MIP project will provide an analysis of the full suite of results. Furthermore, all simulation results are being made publicly available (see the "Code and data availability" section) to enable the whole community to analyse and interpret results.

While we did not have any overlap in terms of different modelling groups using the same model or software framework in a specific region (or at global scales), to tackle this situation in future Fish-MIP protocols, specifically the potential for different modelling groups to make differing configuration decisions, we plan to update our documentation associated with each simulation run to include the full configuration of choices that were made. The Fish-MIP v1.0 protocol will necessarily be revised and revisited, as new climate and fishing data become available as new ecosystem models are included within Fish-MIP (which is encouraged), as the shared understanding of approaches to marine ecosystem modelling increases, and as existing models evolve. The most recent protocol for ISIMIP simulation round $2 \mathrm{~A}$ is available at https://www.isimip.org/protocol/\#isimip2A.

\section{Conclusions}

We believe that the broad intercomparison of marine ecosystem models facilitated by Fish-MIP provides a useful step towards improving our understanding of the future of the marine realm and catalysing the development and uptake of these models. The wide diversity of marine ecosystem mod- 
els provides a healthy spread of perspectives on what are ultimately very complex biological and ecological systems and may provide insight into critical processes that may be incorporated in only a subset of models. We expect that, as in other sectors, model intercomparison will help identify processes that are under-represented or misrepresented in individual models or model types and spur model improvement. Here we have described the Fish-MIP project and protocol in preparation for forthcoming model comparisons at multiple scales. We hope that material compiled for Fish-MIP will inform other intercomparison projects and drive interactions between marine ecosystem modellers and those working in other disciplines. Several marine ecosystem models included in Fish-MIP have already supported projections of the future state of the seas and climate impacts on fisheries. The Fish-MIP intercomparison will add to this by systematically highlighting the uncertainty associated with different model structures and assumptions. This will ultimately improve our capacity to convey the limitations of any advice on future states of marine ecosystems and fisheries and to quantify the benefits and risks associated with alternate management, adaptation, or mitigation options.

Code and data availability. The experimental protocol has no code associated with it. The protocol is described in this paper, the Supplement, and can also be downloaded from https://www.isimip.org/protocol/\#isimip2a (for simulation round 2A). The Fish-MIP website is https: //www.isimip.org/gettingstarted/marine-ecosystems-fisheries/. Forcing data from CMIP5 used for the Fish-MIP simulation round $2 \mathrm{~A}$ are available on the ISIMIP servers (https://www.isimip.org/gettingstarted/\#how-to-join-isimip);

fisheries forcing data for specific fished model runs and models are available by contacting individual Fish-MIP modelling groups. Fish-MIP results from simulation round $2 \mathrm{~A}$ are publicly available for regional (Eddy et al., 2018) and for global (Tittensor et al., 2018) model outputs.

\section{The Supplement related to this article is available online at https://doi.org/10.5194/gmd-11-1421-2018- supplement.}

Author contributions. DPT, TDE, HKL, EDG, WC, JS, and VH led the development of the protocol, with contributions from the other authors. DPT led the writing of the text. All authors contributed to the text.

Competing interests. The authors declare that they have no conflict of interest.

Acknowledgements. Financial support was provided by the German Federal Ministry of Education and Research (BMBF; grant no. 01LS1201A1) through the Inter-Sectoral Impact Model Intercomparison Project (ISIMIP). We thank Reg Watson for supporting CMIP5 data preparation, and we thank John Dunne and Keith Lindsay for helping provide us with access to ESM outputs. Derek P. Tittensor thanks the Kanne Rassmussen Foundation, Denmark and the Cambridge Conservation Initiative (grant CCI-05-14-018) for financial support that facilitated work on this paper. Additional financial support for the CMIP5 input data preparation was provided by the Australian Research Council Discovery project (DP140101377). Heike K. Lotze acknowledges financial support from the Natural Sciences and Engineering Research Council (NSERC) of Canada. Julia L. Blanchard acknowledges the UK Natural Environment Research Council and Department for Environment, Food and Rural Affairs (grant number NE/L003279/1). Susa Niiranen acknowledges support from the NordForsk-funded project Green Growth Based on Marine Resources: Ecological and Socio-Economic Constraints. Marta Coll was partially funded by the European Commission through the Marie Curie Career Integration Grant Fellowships (PCIG10-GA-2011-303534) to the BIOWEB project. Simon Jennings acknowledges support from the UK Department of Environment, Food and Rural Affairs. Jose A. Fernandes received funding from the European Union Horizon 2020 research and innovation programme under grant number 35678193 (Climate Change and European Aquatic Resources) and further funding through the Gipuzkoa Talent Fellowships programme, by the Gipuzkoa Provincial Council, Spain. Yunne-Jai Shin and Ricardo Oliveros-Ramos were partly funded through the EMIBIOS project (FRB Fondation pour la Recherche sur la Biodiversité; contract no. APP-SCEN-2010-II). Ricardo Oliveros-Ramos is grateful for financial support from the IMARPE-PRODUCE-IADB Project "Adaptation to climate change of the fishery sector and marine-coastal ecosystem of Perú" (PE-G1001/PE-T1297). Beth Fulton acknowledges funding from both the Fisheries Research and Development Corporation and CSIRO. Eric Galbraith acknowledges funding from the European Research Council (ERC) under the European Union's Horizon 2020 research and innovation programme (grant agreement no. 682602)

Edited by: Andrew Yool

Reviewed by: Kenneth Rose and one anonymous referee

\section{References}

Andersen, K. H. and Beyer, J. E.: Asymptotic size determines species abundance in the marine size spectrum, Am. Nat., 168, 54-61, 2006.

Andersen, K. P. and Ursin, E.: A multispecies extension to the Beverton and Holt theory of fishing, with accounts of phosphorous circulation and primary production, Medd. Dan. Fisk. Havunders, N. S., 7, 319-345, 1977.

Anticamara, J. A., Watson, R., Gelchu, A., and Pauly, D.: Global fishing effort (1950-2010): Trends, gaps, and implications, Fish. Res., 107, 131-136, https://doi.org/10.1016/j.fishres.2010.10.016, 2011.

Arreguin-Sanchez, F.: Catchability: a key parameter for fish stock assessment, Rev. Fish Biol. Fish., 6, 221-242, 1996. 
Barange, M., Merino, G., Blanchard, J. L., Scholtens, J., Harle, J., Allison, E. H., Allen, J. I., Holt, J., and Jennings, S.: Impacts of climate change on marine ecosystem production in societies dependent on fisheries, Nat. Clim. Chang., 4, 211-216, https://doi.org/10.1038/NCLIMATE2119, 2014.

Béné, C., Barange, M., Subasinghe, R., Pinstrup-Andersen, P., Merino, G., Hemre, G.-I., and Williams, M.: Feeding 9 billion by 2050 - Putting fish back on the menu, Food Secur., 7, 261274, https://doi.org/10.1007/s12571-015-0427-z, 2015.

Benoît, E. and Rochet, M. J.: A continuous model of biomass size spectra governed by predation and the effects of fishing on them, J. Theor. Biol., 226, 9-21, https://doi.org/10.1016/S00225193(03)00290-X, 2004.

Bernhardt, J. R. and Leslie, H. M.: Resilience to Climate Change in Coastal Marine Ecosystems, Ann. Rev. Mar. Sci., 5, 371-392, https://doi.org/10.1146/annurev-marine-121211-172411, 2013.

Blanchard, J. L., Jennings, S., Law, R., Castle, M. D., McCloghrie, P., Rochet, M. J., and Benoît, E.: How does abundance scale with body size in coupled size-structured food webs?, J. Anim. Ecol., 78, 270-280, https://doi.org/10.1111/j.1365-2656.2008.01466.x, 2009.

Blanchard, J. L., Jennings, S., Holmes, R., Harle, J., Merino, G., Allen, J. I., Holt, J., Dulvy, N. K., and Barange, M.: Potential consequences of climate change for primary production and fish production in large marine ecosystems, Philos. Trans. R. Soc. B Biol. Sci., 367, 2979-2989, https://doi.org/10.1098/rstb.2012.0231, 2012.

Blanchard, J. L., Andersen, K. H., Scott, F., Hintzen, N. T., Piet, G., and Jennings, S.: Evaluating targets and trade-offs among fisheries and conservation objectives using a multispecies size spectrum model, J. Appl. Ecol., 51, 612-622, https://doi.org/10.1111/1365-2664.12238, 2014.

Blanchard, J. L., Watson, R. A., Fulton, E. A., Cottrell, R. S., Nash, K. L., Bryndum-Buchholz, A., Büchner, M., Carozza, D. A., Cheung, W. W. L., Elliott, J., Davidson, L. N. K., Dulvy, N. K., Dunne, J. P., Eddy, T. D., Galbraith, E., Lotze, H. K., Maury, O., Müller, C., Tittensor, D. P., and Jennings, S.: Linked sustainability challenges and trade-offs among fisheries, aquaculture and agriculture, Nat. Ecol. Evol., 1, 1240-1249, 2017.

Bopp, L., Resplandy, L., Orr, J. C., Doney, S. C., Dunne, J. P., Gehlen, M., Halloran, P., Heinze, C., Ilyina, T., Séférian, R., Tjiputra, J., and Vichi, M.: Multiple stressors of ocean ecosystems in the 21st century: projections with CMIP5 models, Biogeosciences, 10, 6225-6245, https://doi.org/10.5194/bg-106225-2013, 2013.

Borgmann, U.: Models on the slope of, and biomass flow up, the biomass size spectrum, Can. J. Fish. Aquat. Sci., 44, s136-s140, https://doi.org/10.1139/f87-316, 1987.

Boudreau, P. R., Dickie, L. M., and Kerr, S. R.: Body-size spectra of production and biomass as system-level indicators of ecological dynamics, J. Theor. Biol., 152, 329-339, 1991.

Cabré, A., Marinov, I., Bernardello, R., and Bianchi, D.: Oxygen minimum zones in the tropical Pacific across CMIP5 models: mean state differences and climate change trends, Biogeosciences, 12, 5429-5454, https://doi.org/10.5194/bg-12-54292015, 2015.

Capone, D. G., Zehr, J. P., Paerl, H. W., Bergman, B., and Carpenter, E. J.: Trichodesmium, a Globally Significant Marine Cyanobacterium, Science, 276, 1221-1229, 1997.
Carozza, D. A., Bianchi, D., and Galbraith, E. D.: The ecological module of BOATS-1.0: a bioenergetically constrained model of marine upper trophic levels suitable for studies of fisheries and ocean biogeochemistry, Geosci. Model Dev., 9, 1545-1565, https://doi.org/10.5194/gmd-9-1545-2016, 2016.

Carozza, D. A., Bianchi, D., Galbraith, E. D., Da, C., Bianchi, D., Ed, G., and Bombardier, J.-A.: Formulation, General Features and Global Calibration of a Bioenergetically-Constrained Fishery Model, PLoS One, 12, 1-28, https://doi.org/10.1371/journal.pone.0169763, 2017.

Cheung, W. W. L., Dunne, J., Sarmiento, J. L., and Pauly, D.: Integrating ecophysiology and plankton dynamics into projected maximum fisheries catch potential under climate change in the Northeast Atlantic, ICES J. Mar. Sci., 68, 1008-1018, https://doi.org/10.1093/icesjms/fsr012, 2011.

Cheung, W. W. L., Watson, R., and Pauly, D.: Signature of ocean warming in global fisheries catch, Nature, 497, 365-368, 2013.

Cheung, W. W. L., Frolicher, T. L., Asch, R. G., Jones, M. C., Pinsky, M. L., Reygondeau, G., Rodgers, K. B., Rykaczewski, R. R., Sarmiento, J. L., Stock, C., and Watson, J. R.: Building confidence in projections of the responses of living marine resources to climate change, ICES J. Mar. Sci., 73, 1283-1296, https://doi.org/10.1093/icesjms/fsv250, 2016a.

Cheung, W. W. L., Jones, M. C., Reygondeau, G., Stock, C. A., Lam, V. W. Y., and Frölicher, T. L.: Structural uncertainty in projecting global fisheries catches under climate change, Ecol. Modell., 325, 57-66, https://doi.org/10.1016/j.ecolmodel.2015.12.018, 2016b.

Christensen, V. and Walters, C. J.: Ecopath with Ecosim: methods, capabilities and limitations, Ecol. Modell., 172, 109-139, https://doi.org/10.1016/j.ecolmodel.2003.09.003, 2004.

Christensen, V., Coll, M., Steenbeek, J., Buszowski, J., Chagaris, D., and Walters, C. J.: Representing Variable Habitat Quality in a Spatial Food Web Model, Ecosystems, 17, 1397-1412, https://doi.org/10.1007/s10021-014-9803-3, 2014.

Christensen, V., Coll, M., Buszowski, J., Cheung, W. W. L., Frölicher, T., Steenbeek, J., Stock, C. A., Watson, R. A., and Walters, C. J.: The global ocean is an ecosystem: simulating marine life and fisheries, Global Ecol. Biogeogr., 24, 507-517, https://doi.org/10.1111/geb.12281, 2015.

Coll, M., Lotze, H. K., and Romanuk, T. N.: Structural Degradation in Mediterranean Sea Food Webs: Testing Ecological Hypotheses Using Stochastic and Mass-Balance Modelling, Ecosystems, 11, 939-960, https://doi.org/10.1007/s10021-008-9171-y, 2008.

Coll, M., Akoglu, E., Arreguín-Sánchez, F., Fulton, E. A., Gascuel, D., Heymans, J. J., Libralato, S., Mackinson, S., Palomera, I., Piroddi, C., Shannon, L. J., Steenbeek, J., Villasante, S., and Christensen, V.: Modelling dynamic ecosystems: venturing beyond boundaries with the Ecopath approach, Rev. Fish Biol. Fish., 25, 413-424, https://doi.org/10.1007/s11160-015-9386-x, 2015.

Colleter, M., Valls, A., Guitton, J., Gascuel, D., Pauly, D., and Christensen, V.: Global overview of the applications of the Ecopath with Ecosim modeling approach using the EcoBase models repository, Ecol. Modell., 302, 42-53, 2015.

Dickie, L. M., Kerr, S. R., Boudreau, P. R., Monographs, E., and Sep, N.: Size-Dependent Processes Underlying Regularities in Ecosystem Structure, Ecol. Monogr., 57, 233-250, https://doi.org/10.2307/2937082, 1987. 
Eddy, T., Bulman, C. M., Cheung, W., Coll, M., Fulton, E. A., Galbraith, E., Lotze, H. K., Mackinson, S., Niiranen, S., OliverosRamos, R., Piroddi, C., Steenbeek, J., Tittensor, D. P., Walker, N. D., Schewe, J., Volkholz, J., and Büchner, M.: ISIMIP2a Simulation Data from Marine Ecosystems and Fisheries (regional) Sector, GFZ Data Services, https://doi.org/10.5880/PIK.2018.004, in review, 2018.

Eyring, V., Bony, S., Meehl, G. A., Senior, C. A., Stevens, B., Stouffer, R. J., and Taylor, K. E.: Overview of the Coupled Model Intercomparison Project Phase 6 (CMIP6) experimental design and organization, Geosci. Model Dev., 9, 1937-1958, https://doi.org/10.5194/gmd-9-1937-2016, 2016.

FAO: The State of World Fisheries and Aquaculture 2014, Rome, United Nations Food and Agriculture Organization, 2014.

Fernandes, J. A., Cheung, W. W. L., Jennings, S., Butenschön, M., De Mora, L., Frölicher, T. L., Barange, M., and Grant, A.: Modelling the effects of climate change on the distribution and production of marine fishes: Accounting for trophic interactions in a dynamic bioclimate envelope model, Global Chang. Biol., 19, 2596-2607, https://doi.org/10.1111/gcb.12231, 2013.

Fernandes, J. A., Kay, S., Hossain, M. A. R., Ahmed, M., Cheung, W. W. L., Lazar, A. N., and Barange, M.: Projecting marine fish production and catch potential in Bangladesh in the 21st century under long-term environmental change and management scenarios, ICES J. Mar. Sci., 73, 1357-1369, https://doi.org/10.1093/icesjms/fsv217, 2016.

Fernandes, J. A., Papathanasopoulou, E., Hattam, C., Queirós, A. M., Cheung, W. W. W. L., Yool, A., Artioli, Y., Pope, E. C., Flynn, K. J., Merino, G., Calosi, P., Beaumont, N., Austen, M. C., Widdicombe, S., and Barange, M.: Estimating the ecological, economic and social impacts of ocean acidification and warming on UK fisheries, Fish Fish., 18, 389-411, https://doi.org/10.1111/faf.12183, 2017.

Field, C., Behrenfeld, M., Randerson, J., and Falkowski, P.: Primary Production of the Biosphere: Integrating Terrestrial and Oceanic Components, Science, 281, 237-240, https://doi.org/10.1126/science.281.5374.237, 1998.

Fish-MIP: available at: https://www.isimip.org/gettingstarted/ marine-ecosystems-fisheries/, last access: 28 March, 2018.

Fu, C., Perry, R. I., Shin, Y. J., Schweigert, J., and Liu, H.: An ecosystem modelling framework for incorporating climate regime shifts into fisheries management, Prog. Oceanogr., 115, 53-64, https://doi.org/10.1016/j.pocean.2013.03.003, 2013.

Fulton, E. A.: Approaches to end-to-end ecosystem models, J. Mar. Syst., 81, 171-183, https://doi.org/10.1016/j.jmarsys.2009.12.012, 2010.

Fulton, E. A. and Link, J. S.: Modeling Approaches for Marine Ecosystem-based Management, in: The Sea: Volume 16, Marine Ecosystem-Based Management, edited by: Fogarty, M. J. and McCarthy, J. J., Harvard University Press, 2014.

Fulton, E. A. and Smith, A. D. M.: Lessons learnt from a comparison of three ecosystem models for Port Phillip Bay, Australia, African J. Mar. Sci., 26, 219-243, https://doi.org/10.2989/18142320409504059, 2004.

Fulton, E. A., Smith, A., and Punt, A.: Which ecological indicators can robustly detect effects of fishing?, ICES J. Mar. Sci., 62, 540 551, https://doi.org/10.1016/j.icesjms.2004.12.012, 2005.

Fulton, E. A., Link, J. S., Kaplan, I. C., Savina-Rolland, M., Johnson, P., Ainsworth, C., Horne, P., Gorton, R., Gamble, R.
J., Smith, A. D. M., and Smith, D. C.: Lessons in modelling and management of marine ecosystems: the Atlantis experience, Fish Fish., 12, 171-188, https://doi.org/10.1111/j.14672979.2011.00412.x, 2011.

Fulton, E. A., Smith, A. D. M., Smith, D. C., and Johnson, P.: An integrated approach is needed for ecosystem based fisheries management: Insights from ecosystemlevel management strategy evaluation, PLoS One, 9, 1-16, https://doi.org/10.1371/journal.pone.0084242, 2014.

Griffies, S. M., Danabasoglu, G., Durack, P. J., Adcroft, A. J., Balaji, V., Böning, C. W., Chassignet, E. P., Curchitser, E., Deshayes, J., Drange, H., Fox-Kemper, B., Gleckler, P. J., Gregory, J. M., Haak, H., Hallberg, R. W., Heimbach, P., Hewitt, H. T., Holland, D. M., Ilyina, T., Jungclaus, J. H., Komuro, Y., Krasting, J. P., Large, W. G., Marsland, S. J., Masina, S., McDougall, T. J., Nurser, A. J. G., Orr, J. C., Pirani, A., Qiao, F., Stouffer, R. J., Taylor, K. E., Treguier, A. M., Tsujino, H., Uotila, P., Valdivieso, M., Wang, Q., Winton, M., and Yeager, S. G.: OMIP contribution to CMIP6: experimental and diagnostic protocol for the physical component of the Ocean Model Intercomparison Project, Geosci. Model Dev., 9, 3231-3296, https://doi.org/10.5194/gmd-9-32312016, 2016.

Gruber, N. and Galloway, J. N.: An Earth-system perspective of the global nitrogen cycle, Nature, 451, 293-296, 2008.

Hamblin, J. D.: Oceanographers and the cold war, University of Washington Press, Seattle, 2005.

Harfoot, M. B. J., Newbold, T., Tittensor, D. P., Emmott, S., Hutton, J., Lyutsarev, V., Smith, M. J., Scharlemann, J. P. W., and Purves, D. W.: Emergent global patterns of ecosystem structure and function from a mechanistic general ecosystem model, PLoS Biol., 12, e1001841, https://doi.org/10.1371/journal.pbio.1001841, 2014.

Hawkins, E. and Sutton, R.: The potential to narrow uncertainty in regional climate predictions, Bull. Am. Meteorol. Soc., 90, 1095-1107, 2009.

Hollowed, A. B., Bax, N., Beamish, R., Collie, J., Fogarty, M., Livingston, P., Pope, J., and Rice, J. C.: Are multispecies models an improvement on single-species models for measuring fishing impacts on marine ecosystems?, ICES J. Mar. Sci., 57, 707-719, 2000.

Holt, J., Schrum, C., Cannaby, H., Daewel, U., Allen, I., Artioli, Y., Bopp, L., Butenschon, M., Fach, B. A., Harle, J., Pushpadas, D., Salihoglu, B., and Wakelin, S.: Potential impacts of climate change on the primary production of regional seas: A comparative analysis of five European seas, Prog. Oceanogr., 140, 91 115, https://doi.org/10.1016/j.pocean.2015.11.004, 2016.

Huber, V., Schellnhuber, H. J., Arnell, N. W., Frieler, K., Friend, A. D., Gerten, D., Haddeland, I., Kabat, P., LotzeCampen, H., Lucht, W., Parry, M., Piontek, F., Rosenzweig, C., Schewe, J., and Warszawski, L.: Climate impact research: beyond patchwork, Earth Syst. Dynam., 5, 399-408, https://doi.org/10.5194/esd-5-399-2014, 2014.

ICES (International Council for the Exploration of the Sea): Report of the Working Group on Fish Distribution Shifts (WKFISHDISH), Copenhagen, Denmark, 2016.

ISIMIP: available at: https://www.isimip.org/protocol/\#isimip2a, last access: 28 March, 2018.

ISIMIP: available at: https://www.isimip.org/gettingstarted/ \#how-to-join-isimip/, last access: 28 March, 2018. 
Jennings, S. and Collingridge, K.: Predicting consumer biomass, size-structure, production, catch potential, responses to fishing and associated uncertainties in the world's marine ecosystems, PLoS One, 10, e0133794, https://doi.org/10.1371/journal.pone.0133794, 2015.

Jennings, S., Kaiser, M. J., and Reynold, J. D.: Marine Fisheries Ecology, Blackwell, Oxford, 2001.

Jennings, S., Andersen, K. H., and Blanchard, J. L.: Marine ecology and fisheries, in: Metabolic ecology - a scaling approach, edited by: Sibly, R. M., Brown, J. H., and Kodric-Brown, A., p. 375, John Wiley, Chichester, 2012.

Jones, M. C. and Cheung, W. W. L.: Multi-model ensemble projections of climat change effects on global marine biodiversity, ICES J, 72, 741-752, 2015.

Jones, M. C., Dye, S. R., Fernandes, J. A., Frölicher, T. L., Pinnegar, J. K., Warren, R., and Cheung, W. W. L.: Predicting the Impact of Climate Change on Threatened Species in UK Waters, PLoS One, 8, 1-13, https://doi.org/10.1371/journal.pone.0054216, 2013.

Lehodey, P., Senina, I., and Murtugudde, R.: A spatial ecosystem and populations dynamics model (SEAPODYM) - Modeling of tuna and tuna-like populations, Prog. Oceanogr., 78, 304-318, https://doi.org/10.1016/j.pocean.2008.06.004, 2008.

Lehodey, P., Murtugudde, R., and Senina, I.: Bridging the gap from ocean models to population dynamics of large marine predators: A model of mid-trophic functional groups, Prog. Oceanogr., 84, 69-84, https://doi.org/10.1016/j.pocean.2009.09.008, 2010.

Lehodey, P., Senina, I., Nicol, S., and Hampton, J.: Modelling the impact of climate change on South Pacific albacore tuna, Deep Sea Res. Part II Top. Stud. Oceanogr., 113, 246-259, https://doi.org/10.1016/j.dsr2.2014.10.028, 2015.

Maury, O.: An overview of APECOSM, a spatialized mass balanced "Apex Predators ECOSystem Model" to study physiologically structured tuna population dynamics in their ecosystem, Prog. Oceanogr., 84, 113-117, https://doi.org/10.1016/j.pocean.2009.09.013, 2010.

Maury, O. and Poggiale, J. C.: From individuals to populations to communities: A dynamic energy budget model of marine ecosystem size-spectrum including life history diversity, J. Theor. Biol., 324, 52-71, https://doi.org/10.1016/j.jtbi.2013.01.018, 2013.

Maury, O., Shin, Y. J., Faugeras, B., Ben Ari, T., and Marsac, F.: Modeling environmental effects on the size-structured energy flow through marine ecosystems. Part 2: Simulations, Prog. Oceanogr., 74, 500-514, https://doi.org/10.1016/j.pocean.2007.05.001, 2007.

Maury, O., Campling, L., Arrizabalaga, H., Aumont, O., Bopp, L., Merino, G., Squires, D., Cheung, W., Goujon, M., Guivarch, C., Lefort, S., Marsac, F., Monteagudo, P., Murtugudde, R., Österblom, H., Pulvenis, J. F., Ye, Y., and van Ruijven, B. J.: From shared socio-economic pathways (SSPs) to oceanic system pathways (OSPs): Building policy-relevant scenarios for global oceanic ecosystems and fisheries, Global Environ. Change, 45, 203-216, https://doi.org/10.1016/j.gloenvcha.2017.06.007, 2017.

Merino, G., Barange, M., Blanchard, J. L., Harle, J., Holmes, R., Allen, I., Allison, E. H., Badjeck, M. C., Dulvy, N. K., Holt, J., Jennings, S., Mullon, C., and Rodwell, L. D.: Can marine fisheries and aquaculture meet fish demand from a growing human population in a changing climate?, Global Environ. Change,
22, 795-806, https://doi.org/10.1016/j.gloenvcha.2012.03.003, 2012.

Moore, C. M., Mills, M. M., Arrigo, K. R., Berman-Frank, I., Bopp, L., Boyd, P. W., Galbraith, E. D., Geider, R. J., Guieu, C., Jaccard, S. L., Jickells, T. D., La Roche, J., Lenton, T. M., Mahowald, N. M., Marañón, E., Marinov, I., Moore, J. K., Nakatsuka, T., Oschlies, A., Saito, M. A., Thingstad, T. F., Tsuda, A., and Ulloa, O.: Processes and patterns of oceanic nutrient limitation, Nat. Geosci., 6, 701-710, https://doi.org/10.1038/ngeo1765, 2013.

Mora, C., Tittensor, D. P., Adl, S., Simpson, A. G. B., and Worm, B.: How Many Species Are There on Earth and in the Ocean?, edited by: Mace, G. M., PLoS Biol., 9, e1001127, https://doi.org/10.1371/journal.pbio.1001127, 2011.

Mullon, C., Steinmetz, F., Merino, G., Fernandes, J. A., Cheung, W. W. L., Butenschön, M., and Barange, M.: Quantitative pathways for Northeast Atlantic fisheries based on climate, ecologicaleconomic and governance modelling scenarios, Ecol. Modell., 320, 273-291, https://doi.org/10.1016/j.ecolmodel.2015.09.027, 2016.

Nielsen, J. R., Thunberg, E., Holland, D. S., Schmidt, J. O., Fulton, E. A., Bastardie, F., Punt, A. E., Allen, I., Bartelings, H., Bertignac, M., Bethke, E., Bossier, S., Buckworth, R., Carpenter, G., Christensen, A., Christensen, V., Da-Rocha, J. M., Deng, R., Dichmont, C., Doering, R., Esteban, A., Fernandes, J. A., Frost, H., Garcia, D., Gasche, L., Gascuel, D., Gourguet, S., Groeneveld, R. A., Guillén, J., Guyader, O., Hamon, K. G., Hoff, A., Horbowy, J., Hutton, T., Lehuta, S., Little, L. R., Lleonart, J., Macher, C., Mackinson, S., Mahevas, S., Marchal, P., Mato-Amboage, R., Mapstone, B., Maynou, F., Merzéréaud, M., Palacz, A., Pascoe, S., Paulrud, A., Plaganyi, E., Prellezo, R., van Putten, E. I., Quaas, M., Ravn-Jonsen, L., Sanchez, S., Simons, S., Thébaud, O., Tomczak, M. T., Ulrich, C., van Dijk, D., Vermard, Y., Voss, R., and Waldo, S.: Integrated ecological-economic fisheries models-Evaluation, review and challenges for implementation, Fish Fish., 19, 1-29, https://doi.org/10.1111/faf.12232, 2017.

Niiranen, S., Yletyinen, J., Tomczak, M. T., Blenckner, T., Hjerne, O., Mackenzie, B. R., Müller-Karulis, B., Neumann, T., and Meier, H. E. M.: Combined effects of global climate change and regional ecosystem drivers on an exploited marine food web., Global Chang. Biol., 19, 3327-3342, https://doi.org/10.1111/gcb.12309, 2013.

Payne, M. R., Barange, M., Cheung, W. W. L., MacKenzie, B. R., Batchelder, H. P., Cormon, X., Eddy, T. D., Fernandes, J. A., Hollowed, A. B., Jones, M. C., Link, J. S., Neubauer, P., Ortiz, I., Queirós, A. M., and Paula, J. R.: Uncertainties in projecting climate-change impacts in marine ecosystems, ICES J. Mar. Sci., 73, 1272-1282, https://doi.org/10.1093/icesjms/fsv231, 2016.

Pearson, R. G. and Dawson, T. P.: Predicting the impacts of climate change on the distribution of speces: are bioclimate envelope models useful?, Global Ecol. Biogeogr., 12, 361-371, https://doi.org/10.1046/j.1466-822X.2003.00042.x, 2003.

Peck, M. A., Arvanitidis, C., Butenschön, M., Canu, D. M., Chatzinikolaou, E., Cucco, A., Domenici, P., Fernandes, J. A., Gasche, L., Huebert, K. B., Hufnagl, M., Jones, M. C., Kempf, A., Keyl, F., Maar, M., Mahévas, S., Marchal, P., Nicolas, D., Pinnegar, J. K., Rivot, E., Rochette, S., Sell, A. F., Sinerchia, M., Solidoro, C., Somerfield, P. J., Teal, L. R., Travers-Trolet, 
M., and van de Wolfshaar, K. E.: Projecting changes in the distribution and productivity of living marine resources: A critical review of the suite of modelling approaches used in the large European project VECTORS, Estuar. Coast. Shelf Sci., 201, 40-55, https://doi.org/10.1016/j.ecss.2016.05.019, 2016.

Plagányi, É. E.: Models for an ecosystem approach to fisheries, Rome, available at: http://www.fao.org/docrep/010/a1149e/ a1149e00.htm (last ccess: 8 November 2015), 2007.

Plagányi, É. E., Bell, J. D., Bustamante, R. H., Dambacher, J. M., Dennis, D. M., Dichmont, C. M., Dutra, L. X. C., Fulton, E. A., Hobday, A. J., Ingrid van Putten, E., Smith, F., Smith, A. D. M., and Zhou, S.: Modelling climate-change effects on Australian and Pacific aquatic ecosystems: a review of analytical tools and management implications, Mar. Freshw. Res., 62, 1132, https://doi.org/10.1071/MF10279, 2011.

Plagányi, É. E., Punt, A. E., Hillary, R., Morello, E. B., Thébaud, O., Hutton, T., Pillans, R. D., Thorson, J. T., Fulton, E. A., Smith, A. D. M., Smith, F., Bayliss, P., Haywood, M., Lyne, V., and Rothlisberg, P. C.: Multispecies fisheries management and conservation: tactical applications using models of intermediate complexity, Fish Fish., 15, 1-22, https://doi.org/10.1111/j.14672979.2012.00488.x, 2014.

Platt, T. and Denman, K.: The structure of pelagic marine ecosystems, Rapp. Procés-Verbaux des Réunions, Cons. Int. pour l'Exploration la Mer, 173, 60-65, 1978.

Polovina, J. J.: Model of a coral reef ecosystem, Coral Reefs, 3, 1-11, https://doi.org/10.1007/BF00306135, 1984

Pope, J. G., Rice, J. C., Daan, N., Jennings, S., and Gislason, H.: Modelling an exploited marine fish community with 15 parameters - results from a simple size-based model, ICES J. Mar. Sci., 63, 1029-1044, https://doi.org/10.1016/j.icesjms.2006.04.015, 2006.

Pörtner, H.-O., Karl, D. M., Boyd, P. W., Cheung, W. W., LluchCota, S. E., Nojiri, Y., Schmidt, D. N., and Zavialov, P. O.: Ocean Systems, in: Climate Change 2014: Impacts, Adaptation and Vulnerability. Part A: Global and Sectoral Aspects. Contribution of Working Group II to the Fifth Assessment Report of the Intergovernmental Panel on Climate Chagne, edited by: Drinkwater, K. F. and Polonsky, A., 411-484, Cambridge University Press, 2014.

Queirós, A. M., Huebert, K. B., Keyl, F., Fernandes, J. A., Stolte, W., Maar, M., Kay, S., Jones, M. C., Hamon, K. G., Hendriksen, G., Vermard, Y., Marchal, P., Teal, L. R., Somerfield, P. J., Austen, M. C., Barange, M., Sell, A. F., Allen, I., and Peck, M. A.: Solutions for ecosystem-level protection of ocean systems under climate change, Global Chang. Biol., 22, 3927-3936, https://doi.org/10.1111/gcb.13423, 2016.

Randall, D. A., Wood, R. A., Bony, S., Colman, R., Fichefet, T., Fyfe, J., Kattsov, V., Pitman, A., Shukla, J., Srinivasan, J., Stouffer, R. J., Sumi, A., and Taylor, K. E.: Climate models and their evaluation, edited by: Solomon, S., Qin, D., Manning, M., Chen, Z., Marquis, M., Averyt, K. B., Tignor, M., and Miller, H. L., Climate change 2007: The physical science basis. Contribution of Working Group I to the Fourth Assessment Report of the Intergovernmental Panel on Climate Change, Cambridge University Press, Cambridge, 2007.

Ruane, A. C., Teichmann, C., Arnell, N. W., Carter, T. R., Ebi, K. L., Frieler, K., Goodess, C. M., Hewitson, B., Horton, R., Kovats, R. S., Lotze, H. K., Mearns, L. O., Navarra, A., Ojima, D.
S., Riahi, K., Rosenzweig, C., Themessl, M., and Vincent, K.: The Vulnerability, Impacts, Adaptation and Climate Services Advisory Board (VIACS AB v1.0) contribution to CMIP6, Geosci. Model Dev., 9, 3493-3515, https://doi.org/10.5194/gmd-9-34932016, 2016.

Saba, V. S., Griffies, S. M., Anderson, W. G., Winton, M., Alexander, M. A., Delworth, T. L., Hare, J. A., Harrison, M. J., Rosati, A., Vecchi, G. A., and Zhang, R.: Enhanced warming of the Northwest Atlantic Ocean under climate change, J. Geophys. Res. Ocean., 121, 118-132, https://doi.org/10.1002/2015JC011346, 2016.

Schellnhuber, H. J., Frieler, K., and Kabat, P.: The elephant, the blind, and the intersectoral intercomparison of climate impacts., P. Natl. Acad. Sci. USA, 111, 1-3, 2013.

Sheldon, R. W. and Parsons, T. R.: A Continuous Size Spectrurn for Particulate Matter in the Sea, J. Fish. Board Canada, 24, 909915, 1967.

Sheldon, R. W., Prakash, A., and Sutcliffe, H.: The size distribution of particles in the Ocean, Limnol. Oceanogr., 17, 327-340, 1972.

Sheldon, R. W., Sutcliffe Jr., W. H., and Paranjape, M. A.: Structure of pelagic food chain and relationship between plankton and fish production, J. Fish. Res. Board Canada, 34, 2344-2355, 1977.

Shin, Y.-J. and Cury, P.: Using an individual-based model of fish assemblages to study the response of size spectra to changes in fishing, Can. J. Fish. Aquat. Sci., 61, 414-431, 2004.

Shin, Y.-J., Shannon, L. J., and Cury, P. M.: Simulations of fishing effects on the southern Benguela fish community using an individual-based model: learning from a comparison with ECOSIM, African J. Mar. Sci., 26, 95-114, https://doi.org/10.2989/18142320409504052, 2004.

Smith, A. D. M., Brown, C. J., Bulman, C. M., Fulton, E. A., Johnson, P., Kaplan, I. C., Lozano-Montes, H., Mackinson, S., Marzloff, M., Shannon, L. J., Shin, Y.-J., and Tam, J.: Impacts of Fishing Low-Trophic Level Species on Marine Ecosystems, Science, 333, 1147-1150, 2011.

Steenbeek, J., Coll, M., Gurney, L., Mélin, F., Hoepffner, N., Buszowski, J., and Christensen, V.: Bridging the gap between ecosystem modeling tools and geographic information systems: Driving a food web model with external spatial-temporal data, Ecol. Modell., 263, 139-151, https://doi.org/10.1016/j.ecolmodel.2013.04.027, 2013.

Stock, C. A., Alexander, M. A., Bond, N. A., Brander, K. M., Cheung, W. W. L., Curchitser, E. N., Delworth, T. L., Dunne, J. P., Griffies, S. M., Haltuch, M. A., Hare, J. A., Hollowed, A. B., Lehodey, P., Levin, S. A., Link, J. S., Rose, K. A., Rykaczewski, R. R., Sarmiento, J. L., Stouffer, R. J., Schwing, F. B., Vecchi, G. A., and Werner, F. E.: On the use of IPCC-class models to assess the impact of climate on Living Marine Resources, Prog. Oceanogr., 88, 1-27, https://doi.org/10.1016/j.pocean.2010.09.001, 2011.

Sumaila, U. R., Cheung, W., Dyck, A., Gueye, K., Huang, L., Lam, V., Pauly, D., Srinivasan, T., Swartz, W., Watson, R., and Zeller, D.: Benefits of Rebuilding Global Marine Fisheries Outweigh Costs, PLoS One, 7, e40542, https://doi.org/10.1371/journal.pone.0040542, 2012.

Tagliabue, A., Aumont, O., DeAth, R., Dunne, J. P., Dutkiewicz, S., Galbraith, E., Misumi, K., Moore, J. K., Ridgwell, A., Sherman, E., Stock, C., Vichi, M., Völker, C., and Yool, A.: How well do global ocean biogeochemistry models simulate dis- 
solved iron distributions?, Global Biogeochem. Cy., 30, 149174, https://doi.org/10.1002/2015GB005289, 2015.

Taylor, K. E., Stouffer, R. J., and Meehl, G. A.: An overview of CMIP5 and the experiment design, B. Am. Meteorol. Soc., 93, 485-498, 2012.

Tittensor, D. P., Galbraith, E., Barange, M., Barrier, N., Blanchard, J., Bopp, L., Bryndum-Buchholz, A., Carozza, D., Cheung, W., Christensen, V., Coll, M., Eddy, T., Fernandes Salvador, J. A., Hobday, A., Jennings, S., Jones, M., Lehodey, P., Lotze, H. K., Maury, O., Steenbeek, J., Underwood, P. J., Watson, J., Schewe, J., Volkholz, J., and Büchner, M.: ISIMIP2a Simulation Data from Marine Ecosystems and Fisheries (global) Sector, GFZ Data Services, https://doi.org/10.5880/PIK.2018.005, in review, 2018.

Townsend, H. M., Link, J. S., Osgood, T., Gedamke, T., Watters, G. M., Polovina, J. J., Levin, P. S., Cyr, N., and Aydin, K. Y.: National Marine Fisheries Service Report of the National Ecosystem Modeling Workshop (NEMoW), US Department of Commerce, NOAA Technical Memorandum NMFS-F/SPO-87, Silver Spring, MD, 2008.

Travers, M., Shin, Y.-J., Shannon, L., and Cury, P.: Simulating and testing the sensitivity of ecosystem-based indicators to fishing in the southern Benguela ecosystem, Can. J. Fish. Aquat. Sci., 63, 943-956, 2006.

Travers, M., Shin, Y.-J., Jennings, S., and Cury, P.: Towards end-to-end models for investigating the effects of climate and fishing in marine ecosystems, Prog. Oceanogr., 75, 751-770, https://doi.org/10.1016/j.pocean.2007.08.001, 2007.

Travers, M., Shin, Y. J., Jennings, S., Machu, E., Huggett, J. A., Field, J. G., and Cury, P. M.: Two-way coupling versus oneway forcing of plankton and fish models to predict ecosystem changes in the Benguela, Ecol. Modell., 220, 3089-3099, https://doi.org/10.1016/j.ecolmodel.2009.08.016, 2009.
Travers, M., Watermeyer, K., Shannon, L. J., and Shin, Y. J.: Changes in food web structure under scenarios of overfishing in the southern Benguela: Comparison of the Ecosim and OSMOSE modelling approaches, J. Mar. Syst., 79, 101-111, https://doi.org/10.1016/j.jmarsys.2009.07.005, 2010.

Travers-Trolet, M., Shin, Y. J., Shannon, L. J., Moloney, C. L., and Field, J. G.: Combined fishing and climate forcing in the southern Benguela upwelling ecosystem: An end-to-end modelling approach reveals dampened effects, PLoS One, 9, 1-9, https://doi.org/10.1371/journal.pone.0094286, 2014.

UN: The first global integrated marine assessment: World Ocean Assessment I, New York, 2016.

Warszawski, L., Frieler, K., Huber, V., Piontek, F., Serdeczny, O., and Schewe, J.: The Inter-Sectoral Impact Model Intercomparison Project (ISI-MIP): Project framework, P. Natl. Acad. Sci. USA, 1-5, https://doi.org/10.1073/pnas.1312330110, 2013.

Watson, J. R., Stock, C. A., and Sarmiento, J. L.: Exploring the role of movement in determining the global distribution of marine biomass using a coupled hydrodynamic Size-based ecosystem model, Prog. Oceanogr., 138, 521-532, https://doi.org/10.1016/j.pocean.2014.09.001, 2015.

Watson, R. A.: A database of global marine commercial, smallscale, illegal and unreported fisheries catch 1950-2014, Sci Data, 4, 170039, https://doi.org/10.1038/sdata.2017.39, 2017.

Watson, R. A., Cheung, W. W. L., Anticamara, J. A., Sumaila, R. U., Zeller, D., and Pauly, D.: Global marine yield halved as fishing intensity redoubles, Fish Fish., 14, 493-503, https://doi.org/10.1111/J.1467-2979.2012.00483.X, 2013. 